\title{
THE FATAL FIVE? FIVE FACTORS THAT ENHANCE EFFECTIVENESS OF STABILITY OPERATIONS
}

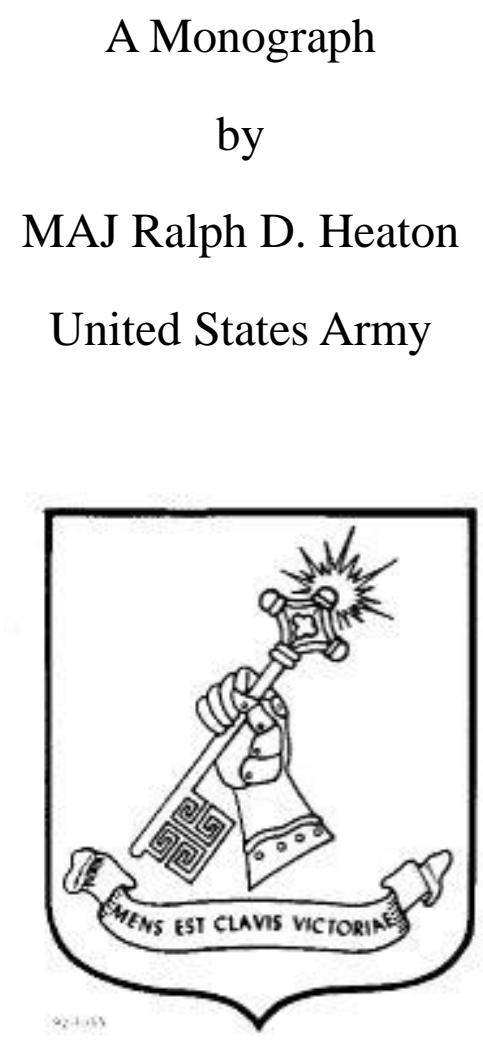

School of Advanced Military Studies

United States Army Command and General Staff College

Fort Leavenworth, Kansas

AY 2014-001 


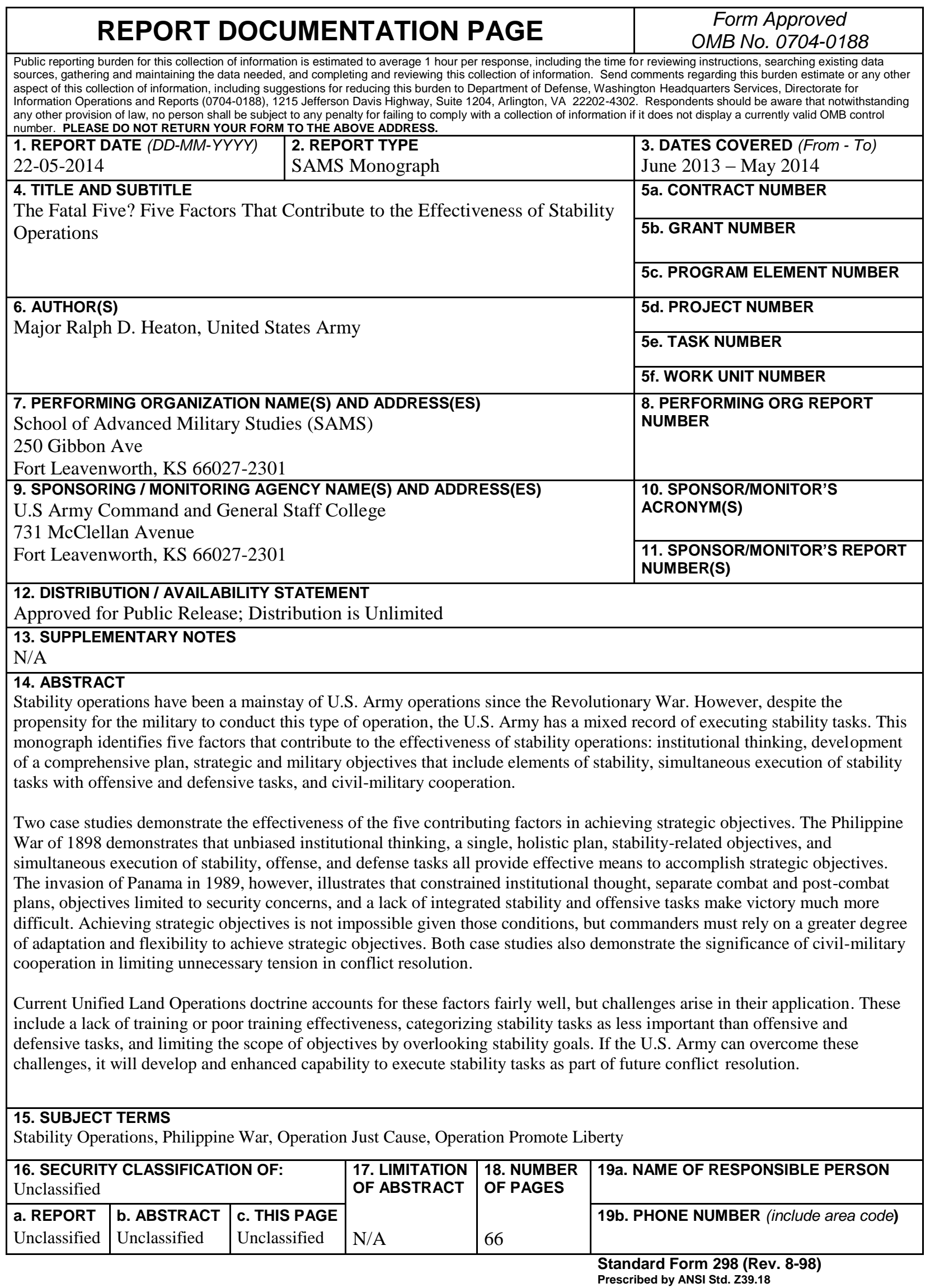




\section{MONOGRAPH APPROVAL}

Name of Candidate: Major Ralph D. Heaton

Monograph Title: The Fatal Five? Five Factors That Enhance Effectiveness of Stability Operations

Approved by:

Mark T. Calhoun, Ph.D. , Monograph Director

Christopher T. Drew, COL, EN , Seminar Leader

Henry A. Arnold III, COL, IN

, Director, School of Advanced Military Studies

Accepted this $22^{\text {nd }}$ day of May 2014 by:

Robert F. Baumann, Ph.D.

, Director, Graduate Degree Programs

The opinions and conclusions expressed herein are those of the student author, and do not necessarily represent the views of the U.S. Army Command and General Staff College or any other government agency. (References to this study should include the foregoing statement.) 


\begin{abstract}
THE FATAL FIVE? FIVE FACTORS THAT ENHANCE EFFECTIVENESS OF STABILITY OPERATIONS, by MAJ Ralph D. Heaton, U.S. Army, 58 pages.
\end{abstract}

Stability operations have been a mainstay of U.S. Army operations since the Revolutionary War. However, despite the propensity for the military to conduct this type of operation the U.S. Army has a mixed record of executing stability tasks. This monograph identifies five factors that contribute to the effectiveness of stability operations: institutional thinking, development of a comprehensive plan, strategic and military objectives that include elements of stability, simultaneous execution of stability tasks with offensive and defensive tasks, and civil-military cooperation.

Two case studies demonstrate the effectiveness of the five contributing factors in achieving strategic objectives. The Philippine War of 1898 demonstrates that unbiased institutional thinking, a single, holistic plan, stability-related objectives, and simultaneous execution of stability, offense, and defense tasks all provide effective means to accomplish strategic objectives. The invasion of Panama in 1989, however, illustrates that constrained institutional thought, separate combat and post-combat plans, objectives limited to security concerns, and a lack of integrated stability and offensive tasks make victory much more difficult. Achieving strategic objectives is not impossible given those conditions, but commanders must rely on a greater degree of adaptation and flexibility to achieve strategic objectives. Both case studies also demonstrate the significance of civil-military cooperation in limiting unnecessary tension in conflict resolution.

Current Unified Land Operations doctrine accounts for these factors fairly well, but challenges arise in their application. These include a lack of training or poor training effectiveness, categorizing stability tasks as less important than offensive and defensive tasks, and limiting the scope of objectives by overlooking stability goals. If the U.S. Army can overcome these challenges, it will develop and enhanced capability to execute stability tasks as part of future conflict resolution. 


\section{TABLE OF CONTENTS}

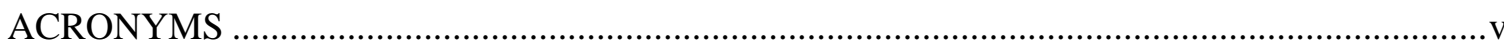

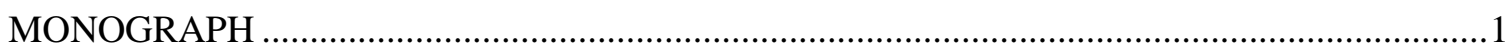

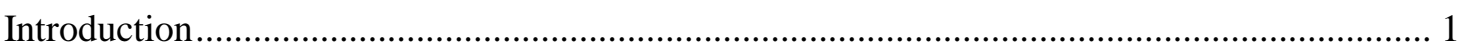

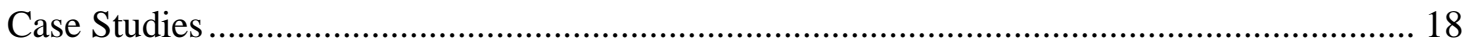

The Philippine War.......................................................................................... 18

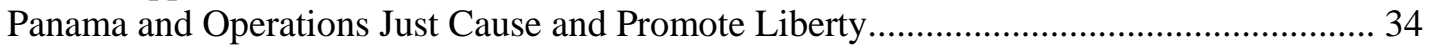

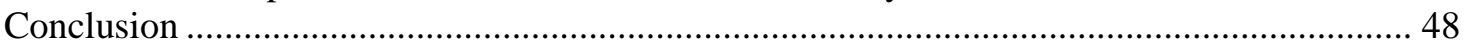

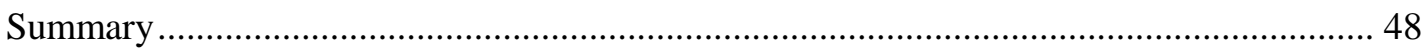

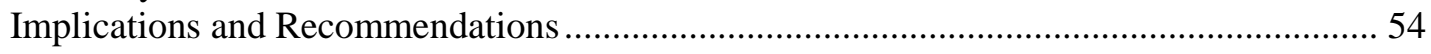

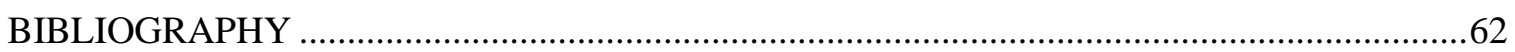




\section{ACRONYMS}

ADP

ADRP

CMOTF

CRC

CSO

DOD

DOS

FM

GOP

ICITAP

JP

JTF-PM

LIC

METL

MSG

NSS

OOTW

PDF

PNP

PRT

SASO

TRADOC

ULO

USAID

USSOUTHCOM
Army Doctrine Publication

Army Doctrine Reference Publication

Civil-Military Operations Task Force

Civilian Response Corps

Office of Conflict and Stabilization Operations

Department of Defense

Department of State

Field Manual

Government of Panama

International Criminal Investigative Training Assistance Program

Joint Publication

Joint Task Force-Panama

Low Intensity Conflict

Mission Essential Task List

Military Support Group

National Security Strategy

Operations Other Than War

Panamanian Defense Forces

Panamanian National Police

Provincial Reconstruction Team

Stability and Support Operations

Training and Doctrine Command

Unified Land Operations

United States Agency for International Development

United States Southern Command 


\section{MONOGRAPH}

\section{$\underline{\text { Introduction }}$}

As defined in the U.S. Army's current operations doctrine, operational art involves the arrangement of tactical actions in time, space, and purpose to achieve strategic objectives. ${ }^{1}$ Some military practitioners interpret "tactical actions" as a reference strictly to battles or engagements. This definition and interpretation has two potential origins. One may lie in the study of Carl von Clausewitz. In Book Four of On War, Clausewitz claimed that fighting as demonstrated through the engagement is the "essential military activity which... comprises the object of war." "Army Doctrine Publication (ADP) 3-0 provided a second potential source of this interpretation. In it, "a tactical action is a battle or engagement, employing lethal or nonlethal actions, designed for a specific purpose in relation to the enemy." It goes on to provide specific examples of tactical actions, none of which include a stability task. ${ }^{3}$

Regardless of the source, such interpretations lead to the separation of stability tasks from offensive and defensive operations as a unique category of tactical actions that do not fit within the overall framework of operational art. The military's role in stability operations to remove sources of instability is the lesser of decisive action tasks. This sentiment began with the end of World War II, and continued through Vietnam to recent conflicts in Iraq and Afghanistan. ${ }^{4}$

${ }^{1}$ Headquarters, Department of the Army, Army Doctrine Publication 3-0, Operations (Washington, DC: Headquarters, Department of the Army, 2011), 9.

${ }^{2}$ Carl von Clausewitz, On War, Indexed Edition, trans. and ed. Michael Howard and Peter Paret (Princeton, NJ: Princeton University Press, 1989), 225.

${ }^{3}$ Headquarters, Department of the Army, ADP 3-0, 7.

${ }^{4}$ Antulio J. Echevarria II, "American Operational Art, 1917-2008," in The Evolution of Operational Art: from Napoleon to the Present (Oxford: Oxford University Press, 2011), 151-3; Gian Gentile, "The Civilian Side," Afghan Quest (blog), January 05, 2011, http://afghanquest.com/ ?tag=colgian-gentile (accessed November 26, 2013). Echevarria argued that the legacy of the two World Wars had a purely conventional warfare influence on the later development of American operational art. He also 
However, policy and doctrine call for a simultaneous application of offensive, defensive, and stability tasks, with equal importance given to each. ${ }^{5}$ This requirement stems from a larger unified action and whole-of-government approach to conflict resolution. Department of Defense Instruction (DODI) 3000.05 identified stability operations as a core military mission and required that the Department of Defense (DOD) conduct those operations with the proficiency equivalent to combat operations. ${ }^{6}$ Early execution of stability tasks reduces the risk of increased violence, increases the security situation, and potentially increases post-conflict success and enhancing recovery efforts. ${ }^{7}$ If modern U.S. Army operational doctrine does not emphasize the importance of stability tasks as tactical actions that can occur simultaneously with offense and defense throughout all phases of an operation, this could limit the Army's effectiveness in future integration of stability operations as a coequal aspect of operational art.

As the U.S. Army prepares to enter another post-war period, it is an appropriate time to review current doctrine and training in an attempt to identify potential opportunities that improve the military's warfighting capabilities. Among these opportunities is to clarify the varying

claimed that while recognizing the need for limited war doctrine, the United States military left that style of warfare to special forces, while conventional forces simply applied more firepower to the situation.

Echevarria made these claims in the context that one can divide warfare into two distinct "grammars": the first grammar of war consists of principles and procedures related to overthrowing an opponent by armed force, while the second grammar relates to limited war such as insurgencies or guerrilla warfare. COL Gian Gentile, a prolific military historian who has written much about counterinsurgency doctrine and America's wars in Iraq and Afghanistan, has argued that stability, when taken in context of nation building and COIN, should take a backseat to offensive and defensive operations focused on the enemy. He supports this claim with the assertions based on his perspective of stability as both less important and simpler than offense and defense.

\footnotetext{
${ }^{5}$ Department of Defense, Department of Defense Instruction 3000.05: Stability Operations (Washington, DC: Department of Defense, 2009), 2; Headquarters, Department of the Army, Army Doctrine Reference Publication 3-07: Stability (Washington, DC: Headquarters, Department of the Army, 2012), 2-1.

${ }^{6}$ Department of Defense, DODI 3000.05, 2.

${ }^{7}$ Headquarters, Department of the Army, ADRP 3-07, 1-2; Gentile, "The Civilian Side," Afghan Quest; SOLLIM Sampler: Targeting Peace and Stability Operations Lessons and Best Practices: Lessons on Stability Operations from U.S. Army War College Students (Carlisle, PA: U.S. Army Peacekeeping and Stability Operations Institute, August 2013), 14, 21.
} 
interpretations of tactical actions and expansion of operational art to include stability tasks. The following analysis provides such a review by evaluating the stability operations component of U.S. Army doctrine, as well as the training the Army conducts for stability operations, to determine whether current doctrine or training methods require modification. Since American involvement in recent wars consisted primarily of stability operations, the analysis compares how well the U.S. Army performed stability tasks in past conflicts within the framework of contemporary doctrine. This provides a basis for assessing the suitability of current stability doctrine and training to prepare the U.S. Army more effectively for likely future operations. From this approach, a few pertinent questions arise. These include how effectively the U.S. Army's Unified Land Operations (ULO) doctrine addresses stability tasks, to what degree the strengths and weaknesses in this doctrine's guidance for stability tasks affects the preparation and execution of those missions, and what areas for sustainment or improvement would make the doctrine more effective in this critical aspect of conflict. The following study analyzes these fundamental issues in the hope that the answers to these questions will offer one means to improve the Army's effectiveness in future integration of stability operations.

While the term "stability operations" has found its way into the modern U.S. Army's everyday vernacular, various uses of the term require clarification for the purpose of this study. Stability tasks make up one third of the methods the U.S. Army uses to conduct decisive action, alongside offensive and defensive tasks. Army Doctrine Reference Publication (ADRP) 1-02: Operational Terms and Military Symbols defines stability tasks as "those tasks conducted as part of operations outside the United States in coordination with other instruments of national power to maintain or reestablish a safe and secure environment and provide essential government services, emergency infrastructure reconstruction, and humanitarian relief." ${ }^{8}$ Army doctrine

\footnotetext{
${ }^{8}$ Headquarters, Department of the Army. Army Doctrine Reference Publication 1-02: Operational
} 
identifies five stability tasks that achieve those desired conditions: establishment of civil security, establishment of civil control, restoration of essential services, support to governance, and support to economic and infrastructure development. ${ }^{9}$

Joint doctrine refers to similar tasks under the term "stability operations," which Joint Publication (JP) 3-07: Stability defines as "various missions, tasks, and activities conducted outside the United States to maintain or reestablish a safe environment, provide essential governmental services, emergency infrastructure, reconstruction, and humanitarian relief." 10 These two definitions show a nuanced difference in that stability operations are a specific type of joint operation along the range of military operations, whereas the U.S. Army's stability tasks are specific tasks conducted during any type of operation across the entire range of military operations. Joint doctrine does not differentiate between different types of tasks within an operation, simply the characterization of the operation itself.

Further, since stability operations require civil-military cooperation, the military practitioner must understand interagency definitions of stability operations. The Department of State (DOS) defines stability as "a characteristic of a state or nation that determines the likelihood to continue or last," while stabilization involves actions "to end or prevent the recurrence of violent conflict and creating conditions for normal economic activity and nonviolent politics."11 To support these definitions, DOS developed a framework for stabilization and reconstruction. Within this framework, five pillars contribute to stabilization, each intended to increase the odds that the United States Government (USG) will achieve long-term success in such operations.

Terms and Military Symbols (Washington, DC: Department of the Army, August 2012), 1-34.

${ }^{9}$ Headquarters, Department of the Army, ADRP 3-07, 2-11.

${ }^{10}$ Joint Staff, Joint Publication 3-07: Stability (Washington, DC: Department of Defense, September 29, 2011), vii.

${ }^{11}$ United States Institute of Peace, Guiding Principles for Stabilization and Reconstruction (Washington, DC: United States Institute of Peace Press, 2009), 11-232. 
These five pillars are a safe and secure environment, rule of law, social well-being, stable governance, and a sustainable economy. ${ }^{12}$ While various organizations conduct and define stability differently, one can see that the approach each takes to such operations complements the others' in language and intent.

The terms "combat" and "conflict" also require defining. These terms are widely used but not found in military doctrine. However, identification of the slight difference between the two is required to establish clarity for the remainder of the paper. The Merriam-Webster dictionary defines combat as "active fighting in war." Very closely related to combat, the dictionary defines conflict as "a struggle for power" or "a difference that prevents agreement." The delineation between the two terms is that combat involves physical harm including the use of weapons, whereas conflict is simply a struggle, armed or unarmed, between two parties. In this sense, armed conflict and combat are synonymous. Conflict must exist for combat to occur, and combat cannot occur in the absence of conflict. Further, post-combat refers to a state of conflict that continues after combat ends. Post-conflict refers to the period after the conflicting parties resolve their differences.

Stability operations and tasks are as much a part of conflict as combat operations. Since the American Revolution, the United States has participated in twenty-eight conflicts of substantial troop commitment. ${ }^{13}$ Though the terminology may have changed throughout history, these commitments usually included a great deal of effort and resources committed to the maintenance of security and functionality of civil processes. Some unusual examples, like Operation Desert Storm, did not involve a significant stability effort. These few cases, however,

\footnotetext{
${ }^{12}$ Guiding Principles for Stabilization and Reconstruction, 1-6.

${ }^{13}$ Lawrence A. Yates, Global War on Terrorism Occasional Paper 15: The U.S. Military's Experience in Stability Operations, 1789-2005 (Fort Leavenworth, KS: Combat Studies Institute Press, 2006), 3 .
} 
prove to be the exception rather than the norm. Since wars increasingly take place near or among civilian populations, the visibility of stability operations has risen in prominence as a necessary part of conflict resolution. ${ }^{14}$ Despite the frequency with which the United States has conducted stability operations - or operations very similar in definition to modern doctrine's stability operations, Army personnel still tend to view their service as first and foremost a warfighting institution. This perspective leads to a record of poor performance in the "second grammar" of war. ${ }^{15}$

After the Vietnam War, the United States Army turned its full attention to preparing for large-scale, mechanized warfare against the Soviet Union. In doing so, it created Air Land Battle doctrine as a means to achieve strategic objectives through integrated tactical actions. This doctrine proved sufficient in preparing the Army for conventional wars - or it seemed so, particularly after America's apparent overwhelming victory in Operations Desert Shield and Desert Storm, but it did not address limited war in detail. This deficiency soon revealed itself in a variety of stability-focused contingency operations in which the U.S. Army struggled to achieve its strategic aims in places like Haiti, Panama, Kosovo, Bosnia, and Somalia. Additionally, worldwide terrorism grew in frequency and severity, finally reaching the American homeland with the devastating attacks of September 11, 2001. This caused the perceived United States victory in the Cold War and position of global hegemony to come into question. The end of the Cold War required a major shift in focus regarding threats to United States vital interests but did not come to fruition. While the military incorporated key aspects of the contemporary threat

\footnotetext{
${ }^{14}$ Rupert Smith, The Utility of Force: The Art of War in the Modern World, (New York: Vintage, 2008), 5, 280. Smith argued, "war as battle in a field between men and machinery, as a massive deciding event ... no longer exists." He claimed that such thinking represents the old paradigm of interstate industrial war, but a new paradigm has taken its place - one of war amongst the people. In short, since WWII, according to Smith, warfare has no longer taken place on the periphery of civilian population centers but within them, leading to an inextricable link between civilians and the wars taking place in their midst.
}

\footnotetext{
${ }^{15}$ Echevarria, 137.
} 
environment of the late 1980s into doctrine, these changes came slowly and minimally throughout the decade between the end of the Cold War and the terrorist attacks of September 11, 2001.

The conclusion of operations in Iraq, an increasingly imminent withdrawal from Afghanistan, and a strategic rebalance toward the Pacific make the present an opportune time to review U.S. Army doctrine and training. While the U.S. Army has performed stability tasks effectively in numerous conflicts since the advent of Air Land Battle doctrine, it has a mixed record of integrating the conduct of stability tasks with conventional operations to achieve desired effects. More often than not, the Army has erred by assuming that it would benefit from immediate interagency action, that its conventional-focused training would prove effective for simultaneous execution of stability tasks, and that it would fill in gaps through battlefield adaptation and organizational formative experiences. The following study highlights five common features that enabled the units involved to integrate stability tasks with offense and defense (with varying success): (1) institutional thinking, (2) development of a comprehensive plan that contains all phases of the operation and stability, offense, and defense tasks, (3) strategic and military objectives that included more than combat-related end states, (4) simultaneous execution of stability tasks with offense and defense, and (5) civil-military cooperation.

Two historical case studies separated by nearly 100 years provide evidence regarding U.S. Army effectiveness in stability operations. The two cases examine the five factors that enabled U.S. forces to align strategic objectives with tactical action - some leading to success, and some that led to less than optimal results that Army personnel should avoid in the future. The first case study, the American campaign in the Philippines during the Spanish-American War and the subsequent Philippine War, provides an example of effective incorporation of stability tasks within nearly all phases and aspects of a major counter-guerilla effort. The second case study, the American invasion of Panama and Operations Just Cause and Promote Liberty, illustrates generally effective conduct of stability tasks, marred by some challenges in integrating stability 
tasks into military operations. Assessment of contemporary doctrine and training from the period of two key stability operations in U.S. Army history provides a basis from which to conduct a comparative analysis of modern doctrine and training, to identify strengths and weaknesses, and identify possible ways to prepare more effectively for future stability operations.

The Philippine campaign of the Spanish-American War and subsequent Philippine War provides an excellent example of effective conduct of stability tasks that complement offensive and defensive tasks. While the overall situation presented long-term challenges for the United States, operations conducted by American forces demonstrated unbiased institutional thinking, development of a comprehensive plan, strategic and military objectives that included elements of stability, and simultaneous execution of stability tasks with offense and defense. The fifth factor, civil-military cooperation, was the exception to effective conduct of stability operations. This area demonstrated one in which commanders of the Philippine War could have improved upon to increase mission effectiveness.

To enable the use of a historical case study that pre-dates use of the term "stability operations," the following analysis equates the term "pacification" with "stability operations." During the Philippine campaign, the U.S. Army viewed "pacification" as all actions taken to establish, maintain, or restore peace. Two main features of pacification were military operations against irregulars and civil operations. ${ }^{16}$ Pacification occurred during the Civil War and Indian Wars and typically involved forcibly suppressing or eliminating a population considered hostile. Such operations sought a balance between reconciliation and repression. ${ }^{17}$ In addition to pacification, President William McKinley used the term "benevolent assimilation.” By this term,

\footnotetext{
${ }^{16}$ Andrew J. Birtle, U.S. Army Counterinsurgency and Contingency Operations Doctrine 18601941 (Washington, DC: Government Printing Office, 1998), 4.

${ }^{17}$ Brian McAllister Linn, The Philippine War, 1899-1902 (Lawrence: University Press of Kansas, 2000), 9 .
} 
McKinley meant well-meaning and kind conversion of others' ways of life to a lifestyle particularly an economy and form of governance - similar to that of the United States. ${ }^{18}$ These definitions and comparisons of terms provide context regarding the approach to stability-like operations of the different eras, when leaders and doctrine used different terms to define otherwise very similar doctrinal concepts and operational tasks.

First, officers during this era expected to conduct operations that included stability tasks ingrained in their institutional thinking. Organizational experience and career development through doctrine, policy, and education provided the foundation for these expectations. U.S. Army doctrine and military policies introduced stability operations and explicitly required U.S. Army officers to conduct stability tasks and assume limited civil administrative roles. Real-world experiences enhanced and solidified understanding of stability operations and reinforced academic instruction. Documents such as General Order 100 issued in 1863 (more commonly known as the Lieber Code), the 1892 Army regulation Troops in Campaign, and officer education curricula in the years before the Philippine War provide abundant evidence of contemporary understanding of stability tasks and provide a framework for evaluating the thinking of commanders prior to combat. ${ }^{19}$

Further, analysis of organizational experiences during the twenty years prior to the war

\footnotetext{
${ }^{18}$ James D Richardson, Messages and Papers of the Presidents 1789-1897 - Volume X (Washington, DC: Government Printing Office, 1899), 220. In his message to the Secretary of War, President McKinley stated it is the "earnest and paramount aim of the military administration to win the confidence, respect, and affection of the inhabitants of the Philippines by assuring to them ... full measure of individual rights and liberties which is in the heritage of free peoples. The mission of the United States is one of benevolent assimilation, substituting the mild sway of justice and right for arbitrary rule ... and to overcome all obstacles to the bestowal of the blessings of good and stable government." By this, McKinley directed the Secretary to win the confidence of the Filipinos and demonstrate their intentions are friendly in order to establish U.S. authority over the Philippines in an amicable manner.

${ }^{19}$ Ramsey, Robert D. III, A Masterpiece of Counterguerrilla Warfare: BG J. Franklin Bell in the Philippines, 1901-1902 ( Fort Leavenworth, KS: Combat Studies Institute Press, 2007), 16; John Fabian Witt, Lincoln's Code: the Laws of War in American History (New York: Free Press, 2013), 2; War Department. Troops in Campaign: Regulations for the Army of the United States (Washington, DC: Government Printing Office, 1892), 2-3.
} 
adds to the formative framework for commander mental models pertaining to execution of stability tasks. Extending the study to the prior twenty years allows the study to account for the typical period of generational change within the military. Very few veterans of the U.S. Civil War served as officers during the Philippine War. By the turn of the century, most Army officers had learned their profession fighting in the frontier wars, domestic policing actions, or limited wars of small troop commitment and short duration. ${ }^{20}$ This organizational experience demonstrates that the military historically performed more than just offensive and defensive tasks. The broad experience better prepared officers to lead troops in the complex environment of the Philippines and demonstrates the benefit of commanders combining their experience with their education to develop theater strategy and operational plans, both of which proved essential to the success of operations within the context of their particular operating environment.

Second, Major General Elwell Otis determined the overall strategy in the Philippines. Although it evolved during the protracted mission, Otis developed a comprehensive strategy. His strategy often specifically highlighted stability in either the ways, such as performing certain stability tasks, or the ends, such pacifying the Filipinos. Upon dissemination of his orders to subordinates, he granted the commanders a good deal of latitude in the execution of his orders through an intent-based approach. This is true of the civil actions guided by his General Order 43 and the integrated offensive operations to destroy the Army of Liberation. ${ }^{21}$ His successor, Major General Arthur MacArthur, followed suit. He developed an overall strategy to achieve pacification, but provided latitude to each commander to determine the specific manner of

\footnotetext{
${ }^{20}$ Maurice Matloff, ed., American Military History, Army Historical Series (1969; repr., Washington, DC: Office of Military History, 1988), 280-300.

${ }^{21}$ Robert D. Ramsey III, Savage Wars of Peace: Case Studies of Pacification in the Philippines, 1900-1902 (Fort Leavenworth, KS: Combat Studies Institute Press, 2007), 20.
} 
execution based on district-level circumstances. ${ }^{22}$

Third, strategic and military objectives explicitly included stability conditions. The Monroe Doctrine, President William McKinley's foreign policy, and correspondence from President McKinley demonstrate strategic communication that clearly articulate policymaker expectations for conditions to end the war. ${ }^{23}$ While they did not develop conceptual, long-term campaign plans as the military does today, those strategic objectives carried over to Otis' objective for VIII Corps. Otis made pacification of the Filipinos a primary goal, and instituted benevolent measures to accomplish it. ${ }^{24}$

Fourth, history demonstrates that leaders synchronized stability tasks with offense and defense operations in the Philippines, integrating those tasks into all aspects of the conflict. From the first U.S. Army units' arrival in the archipelago, military personnel conducted offense, defense, and stability tasks in a simultaneous and synchronized manner. ${ }^{25}$ This simultaneity of execution demonstrates just one aspect of the Army's successful execution of stability tasks.

Fifth, civil-military cooperation was not as effective as it could have been due to personality conflict and tensions between military commanders and civilian officials. For example, President McKinley appointed a small group of advisors led by Dr. Jacob Schurman. McKinley sent the group, known as the Philippine Commission, in March 1899 to resolve Filipino-American disagreements and to report on the feasibility of colonial government. Otis felt Schurman's Commission impeded on his territory and mission, and as a result he marginalized

\footnotetext{
${ }^{22}$ Birtle, 120.

${ }^{23}$ Brian Linn, "War Termination" (Proceedings of the War Termination Conference at USMA, West Point, NY, June 21, 2010), 133; Richardson, 220; Ramsey, A Masterpiece of Counterguerrilla Warfare, 13; Linn, The Philippine War, 1899-1902, 6.

${ }^{24}$ Ramsey, Savage Wars of Peace, 18.

${ }^{25}$ Brian McAllister Linn, U.S. Army and Counterinsurgency in the Philippine War, 1899-1902 (Chapel Hill: The University of North Carolina Press, 2000), 21; Ramsey, Savage Wars of Peace, 19; Ramsey, A Masterpiece of Counterguerrilla Warfare, 95.
} 
the Commission's efforts. ${ }^{26}$ However, after dialogue with Schurman and the departure of the first Philippine Commission, Otis recruited pro-American Filipinos for office and issued General Order 43 for subordinate action. ${ }^{27}$ Major General MacArthur acted similarly with William H. Taft. McKinley sent a second Philippine Commission in August 1900 to "establish municipal and provincial governments and to oversee the transfer of power from the military governor to colonial rule." ${ }^{28}$ MacArthur held a similar relationship with Taft and the second Commission as Otis had with Schurman and the first. Given the personal tensions and MacArthur's focus on the military effort, MacArthur declared martial law through the issuance of General Order 100 and employed Taft as more of an advisor than a superior. ${ }^{29}$

The invasion of Panama provides a contrasting assessment of stability operations than the Philippines. The first four factors provide examples of ineffective preparation for and execution of stability tasks, while the last demonstrates a feature that was effective in the execution of stability operations. American forces and the invasion of Panama demonstrated constrained institutional thinking, separate combat and stability planning, a lack of stability elements in military objectives, and non-simultaneous execution of stability tasks with offensive tasks. However, civil-military cooperation, particularly interaction and coordination with the Government of Panama (GOP), demonstrated a sound and effective method to accomplish stability tasks.

During the invasion of Panama, two terms described operations similar to current stability operations. While doctrine produced the terms sequentially, they slowly evolved from

\footnotetext{
${ }^{26}$ Linn, The Philippine War, 1899-1902, 91.

${ }^{27}$ Ramsey, Savage Wars of Peace, 17-8.

${ }^{28}$ Linn, The Philippine War, 1899-1902, 216.

${ }^{29}$ Ibid., 216.
} 
one to another with a period of overlap. The 1986 version of Field Manual (FM) 100-5:

Operations introduced the term low intensity conflict (LIC), in which Army forces fight irregular or unconventional forces, fully coordinates with national strategy, and includes political and economic activities. ${ }^{30}$ Beginning in 1988, the term operations other than war (OOTW) began to surface, with its formal replacement of LIC in the 1993 version of FM 100-5. OOTW described operations at the end of combat operations that aimed to promote stability, provide humane assistance, and assist U.S. civil authorities. ${ }^{31}$ Such operations ranged from humanitarian assistance and disaster relief to counter-terrorism and counter-insurgency operations. Because the case study occurs when the military used both terms, this monograph maintains the use of LIC throughout for consistency.

First, institutional thinking limited recognition of conflict to some version of large-scale conventional war. Analysis of the 1987 National Security Strategy (NSS) signed by President Ronald Reagan reveals the perceived nature of the strategic environment and the established strategic direction for military action. The 1987 NSS described the Reagan administration's view of a changing world and the evolving nature of global threats. ${ }^{32}$ Despite this recognition, the document identified the Soviets as the highest priority threat, guidance that influenced all preparations for future warfare. The emphasis on the conventional threat presented by the Soviet Union encouraged a generation of Army personnel to neglect preparation for limited warfare. The resulting exclusive emphasis on conventional warfare (mechanized combined arms offense and defense) guided the military as it sought to build an appropriate force structure, prepare suitable doctrine, and provide military education and training designed to shape the Army's role in 1986), 4.

\footnotetext{
${ }^{30}$ Headquarters, Department of the Army, Field Manual 100-5, Operations (Washington, DC
}

${ }^{31}$ Headquarters, Department of the Army, Field Manual 100-5, Operations (Washington, DC: Training and Doctrine Command, 1993), 13-1.

${ }^{32}$ White House, National Security Strategy. (Washington, DC: The White House, 1987), 6. 
supporting national strategy. ${ }^{33}$

Further, evaluation of the 1986 Army's primary operations manual, FM 100-5:

Operations, demonstrates how the Army sought to align doctrine with national strategy. The manual focused on winning the anticipated conventional war against the Soviet Union, leaving the Army ill-prepared for the reality of its immediate future characterized by LIC experience in Lebanon, the Sinai, Grenada, Honduras, and Nicaragua. ${ }^{34}$ Historical accounts related to the effectiveness of stability operations in Panama reveal flaws in the training strategy of the early1980s specifically related to stability tasks, illustrating the impact of contemporary doctrine's exclusive focus on conventional war.

Second, military commanders did not ensure that they possessed a comprehensive plan that encompassed all of the tasks associated with the full scope of an operation like Just Cause. The fact that two plans existed - one for the invasion of Panama and one for the stabilization of the country - demonstrates a disjoined effort to achieve strategic objectives. ${ }^{35}$ Making matters worse, the military planned the operation in two separate headquarters. Upon identification of XVIII Airborne Corps as the Joint Task Force-Panama (JTF-PM) headquarters, United States Southern Command (USSOUTHCOM) only assigned planning responsibility for Operation Just Cause to JTF-PM, leaving the task of post-combat planning to USSOUTHCOM. ${ }^{36}$

Third, while the strategic objectives for operations in Panama enumerated stability-

\footnotetext{
${ }^{33}$ Lawrence A. Yates, The U.S. Military Intervention in Panama: Origins, Planning, and Crisis Management, June 1987-December 1989 (Washington, DC: Center of Military History, 2008), 33.

${ }^{34}$ Headquarters, Department of the Army, FM 100-5 (1986), i.

${ }^{35}$ Richard H. Shultz Jr., In the Aftermath of War U.S. Support for Reconstruction and NationBuilding in Panama Following JUST CAUSE (Maxwell AFB, AL: Air University Press, 1993), 16; John T. Fishel, The Fog of Peace: Planning and Executing the Restoration of Panama (Carlisle Barracks, PA: Strategic Studies Institute, U.S. Army War College, 1992), 25.

${ }^{36}$ Yates, The U.S. Military Intervention in Panama, 269.
} 
related goals, the military did not include stability-related objectives in its plan. ${ }^{37}$ This oversight resulted in ineffective stability planning at the operational level, and focused efforts solely on combat operations during the initial invasion.

Fourth, leaders did not emphasize stability tasks as an important part of conflict. The military rendered stability tasks to a lower status than offensive tasks, and often conducted as an afterthought to combat operations. For example, the lack of an immediate policing function to deal with widespread rioting indicates that the Army did not anticipate the need to integrate this sort of stability task with offensive operations. ${ }^{38}$

Fifth, civil-military cooperation began completely uncoordinated but ended with successful cooperation mechanisms. From the initial authorization to begin planning, the DOD conducted compartmentalized planning at a high level of security classification. ${ }^{39}$ This limited the ability to involve other governmental agencies in the planning, creating an issue of distrust and a lack of integrated tasks and goals among other organizations - particularly the DOS and the United States Agency for International Development (USAID). A month after the invasion, however, with security compartmentalization barriers lifted, military cooperation with civil authorities improved significantly. The Civil-Military Operations Task Force (CMOTF) placed its office in the ministerial building of the newly appointed Government of Panama and liaised on a daily basis. Its personnel coordinated the approval of infrastructure projects with the government, helped indoctrinate a new United States embassy country team and USAID representation, and

\footnotetext{
${ }^{37}$ Bruce W. Watson and Peter G. Tsouras, eds., Operation JUST CAUSE: the U.S. Intervention in Panama (Boulder: Westview Press, 1991), 69.

${ }^{38}$ Shultz, In the Aftermath of War, 28.

${ }^{39}$ Richard H. Shultz Jr., "The Post-Conflict Use of Military Forces: Lessons from Panama, 198991,” The Journal of Strategic Studies 16, no. 2 (June 1993), 150; Fishel, The Fog of Peace, 21.
} 
transitioned responsibilities to civil authorities. ${ }^{40}$

The findings that emerge from comparative analysis of these two cases not only reveal the relative strengths and weaknesses of the U.S. Army's stability efforts during each conflict. It also enables a critical review of today's doctrine to determine how effectively ULO addresses stability tasks, and an estimation of how well this doctrine will facilitate effective training of these tasks. Evaluating contributing factors and current unit Mission Essential Task Lists (METLs) provide evidence for the level of preparedness and potential for effectiveness regarding the conduct of stability tasks.

This study rests upon two major assumptions. First, challenges to the military's effectiveness when conducting stability operations occur when these operations take place alongside or integrated with the execution of offense and defense tasks. Across the range of military operations, those conducted toward the military engagement and security cooperation end of the spectrum tend to have a limited scope and a relatively clearly articulated and limited objective. For example, the National Command Authority assigns foreign humanitarian assistance (FHA) or disaster relief missions with those specific purposes in mind. Rarely do FHA missions require an application of offensive tasks, which might distract Army units from the stability role or assign stability tasks a lower priority.

Second, the military has no influence on the level of commitment or effort on the part of interagency partners, and these agencies will continue to put forth a level of effort similar to that demonstrated in past wars. Interagency response in conflict has historically begun at low levels for a number of reasons - limited personnel with appropriate field experience, low budgets for operations relative to DOD, slower planning and response time, and other factors. ${ }^{41}$ In addition, a

\footnotetext{
${ }^{40}$ Shultz, In the Aftermath of War, 55-6.

${ }^{41}$ Nina M. Serafino, Peacekeeping and Related Stability Operations: Issues of U.S. Military
} 
deteriorated security situation tends to delay interagency involvement, which historically remains relatively low until the level of security within the operating environment increases to the point that it poses an acceptable level of risk to civilian personnel. ${ }^{42}$ Further, interagency partners are civilian organizations and as such, face constraints in their ability to require employees to deploy for any length of time..$^{43}$ To this end, various and random positions within organizations, such as the DOS representative on a Provincial Reconstruction Team (PRT) may go unfilled, leaving capability gaps at the tactical and operational levels. For this reason, the military will continue to conduct stability tasks and operations in future conflicts without assistance from civilian agencies for an unknown period of time. ${ }^{44}$

Involvement (Washington, DC: Congressional Research Service, October 4, 2004), 7; Nina M. Serafino and Martin A. Weiss, Peacekeeping and Conflict Transitions: Background and Congressional Action on Civilian Capabilities (Washington, DC: Congressional Research Service, April 13, 2005$), 3$.

${ }^{42}$ George W. Bush, "Supporting Emerging Democracies" (International Republican Institute Dinner, Renaissance Hotel, Washington, DC, May 17, 2005), http://2001-2009.state.gov/s/ crs/rls/rm/ 46818.htm (accessed December 29, 2013); United States Department of State, "Office of the Coordinator for Reconstruction and Stabilization," January 20, 2009, http://2001-2009.state.gov/s/crs/ (accessed December 29, 2013). In his speech on supporting emerging democracies, President George W. Bush stated "one of the lessons we learned from our experience in Iraq is that, while military personnel can be rapidly deployed anywhere in the world, the same is not true of U.S. government civilians." The Bush administration created the Office of the Coordinator for Reconstruction and Stabilization in July 2004 with an aim of increasing civilian responsiveness. The mission of the O/CRS is "to lead, coordinate and institutionalize USG civilian capacity to prevent or prepare for post-conflict situations, and to help stabilize and reconstruct societies in transition from conflict or civil strife" and "to enhance our nation's institutional capacity to respond to crises involving failing, failed, and post-conflict states."

${ }^{43}$ United States Department of State, “Careers at Department of State.” The Office of Website Management, Bureau of Public Affairs, http://www.state.gov/careers/ (accessed December 29, 2013). At the time of this monograph, all DOS job openings are annotated as voluntary. Thus filling a position is dependent upon the applicant pool. Further, current employees must include a high priority assignment on their preference sheet when due for reassignment. However, they are not under contract, so if selected an employee has the option to terminate their employment in lieu of serving.

${ }^{44}$ Headquarters, Department of the Army, ADRP 3-07, 2-5. ADRP 3-07 acknowledges, "the responsibility for providing for the basic needs of the people rests with the host-nation government or designated civil authorities, agencies, and organizations." However, it also recognized this is not possible in every circumstance. "When not possible, military forces provide minimum levels of civil security and restoration of essential services to the local populace until a civil authority or the host nation is able." It also stated that commanders must resource those stability tasks and that military forces have a moral and legal requirement to conduct minimum essential stability tasks for provision of protection and well-being of the population. 


\section{Case Studies}

The following historical case studies provide evidence regarding U.S. Army effectiveness in stability operations. The first case study, the American campaign in the Philippines during the Spanish-American War and subsequent Philippine War, provides an example of effective stability tasks and operations within the context of a major counter-guerilla effort. The second case study, the American invasion of Panama and Operations Just Cause and Promote Liberty, reveals both effective and ineffective methods for conducting stability tasks and operations within the context of major combat operations. Analysis and comparison of the Army's effectiveness while conducting stability operations during each campaign offers insight for Army leaders as they continue to refine doctrine and training to ensure the Army remains effective at achieving strategic aims.

\section{The Philippine War}

U.S. foreign policy changed significantly during the decade leading up to the SpanishAmerican War. Before this period, manifest destiny and the Monroe Doctrine drove U.S. foreign policy. The United States refrained from venturing outside the homeland, focusing instead on protecting North America from European intrusion..$^{45}$ During the 1880 s, as the United States government grew increasingly aware of its rising prominence in the international order, it began to assert itself more forcefully in support of its expanding interests. ${ }^{46}$ This included a more aggressive view of manifest destiny, which guided foreign policy for the next decade. President Grover Cleveland, during his second term from 1893-1897, temporarily slowed the momentum of

${ }^{45}$ George C. Herring, From Colony to Superpower: U.S. Foreign Relations Since 1776 (New York: Oxford University Press, 2008), 156, 185.

${ }^{46}$ Ibid., 299. 
what many - both Americans and other global powers - saw as American imperialism. ${ }^{47} \mathrm{His}$ refusal to annex Hawaii despite the decade-long rebellion there and strong Republican passion in favor of annexation serves as one example of his strong anti-expansionist beliefs. ${ }^{48}$

The election of President McKinley in 1897 brought with it a more aggressive American foreign policy. ${ }^{49}$ During a Congressional debate on what many viewed as a shift toward American imperialism, McKinley expressed his view that his foreign policy simply involved continental expansion overseas for humanitarian reasons - primarily the responsibility to introduce civilization to savage and degenerate people. Anti-imperialists argued that such overseas expansion represented nothing more than racial dominance and subjection of people to unnecessary intrusion and harsh treatment. ${ }^{50}$ Within a few months of McKinley's election, imperialist policy reigned supreme. Soon, almost every facet of American society began to view Spain's control of Cuba and Puerto Rico as an infringement on American security and interests, leading citizens and their representatives to call for intervention. ${ }^{51}$

In the spring of 1898, after a series of events in Cuba culminating with the sinking of the U.S.S. Maine, public discontent with Spanish tyranny continued to rise. ${ }^{52}$ To demonstrate its dissatisfaction with Spain, the United States Congress voted and approved a declaration of wara rare occurrence - against Spain. ${ }^{53}$ On April 26, 1898, Admiral George Dewey sailed toward the

\footnotetext{
${ }^{47}$ Robert Kagan, Dangerous Nation (New York: Alfred A. Knopf, 2006), 358.

${ }^{48}$ Herring, 306.

${ }^{49}$ Kagan, 388.

${ }^{50}$ Stuart Creighton Miller, "Benevolent Assimilation" The American Conquest of the Philippines, 1899-1903 (New Haven: Yale University Press, 1982), 124-5.

${ }^{51}$ Ibid., 11.

${ }^{52}$ Herring, 13.

${ }^{53}$ Jennifer K. Elsea and Matthew C. Weed, Declarations of War and Authorizations for the Use of
} 
Philippines as ordered by President McKinley. Five days later, Dewey destroyed the Spanish fleet in Manila Bay. ${ }^{54}$ For the next three and half months, Americans supported the Filipinos as they continued their two-year rebellion against the Spaniards. Upon arrival of the U.S. forces in July, the Filipinos captured Manila from the Spanish. The War Department then deployed a larger contingent of Army forces to the Philippines to help with the transition and integration to United States authority - the price the Filipinos would pay for American support in the war, and America's first true foray into imperialism. Spain accepted defeat by signing the Treaty of Paris on December 10, 1898. The Treaty of Paris awarded possession of Cuba, Puerto Rico, Hawaii, Guam, Wake Atoll, and the Philippines to the United States. ${ }^{55}$

The governments of the United States and the Philippines initially enjoyed a positive relationship based on their successful cooperation against the Spaniards. However, tensions between Filipinos and Americans grew when President McKinley decided to annex the Philippines rather than allow the Filipinos to return to a state of self-government and independence once the Army stabilized the situation there. Four months later, on April 11, 1899, Congress ratified a treaty granting McKinley his desire for annexation of the Philippines.

After two years of war against Spain and months of holding out hope for independence after American intervention, the annexation sparked a Filipino insurgency. For the next forty months, U.S. forces and Filipino insurgents battled for control of the population and government. The war, initially consisting only of conventional military actions, evolved into a guerrilla war. The Americans established control over the majority of the archipelago by fall 1901; only the

Military Force: Historical Background and Legal Implications (Washington, DC: Congressional Research Service, January 11, 2013), 1. In the history of the United States up to 2011, there have only been five wars that Congress voted and approved a formal declaration of war under the War Powers Resolution: the War of 1812, the War with Mexico in 1846, the War with Spain in 1898, and both World Wars.

${ }^{54}$ Linn, U.S. Army and Counterinsurgency in the Philippine War, 1899-1902, 1.

${ }^{55}$ Herring, 320. 
three southern Luzon provinces of Batangas, Tayabas, and Cavite continued to resist. ${ }^{56}$ The U.S. Department of Southern Luzon, led by the 3d Separate Brigade, intensified the campaign to subdue the insurgency in the south. General Adna R. Chaffee, commander of the Division of the Philippines, appointed Brigadier General J. Franklin Bell as commander of the 3d Separate Brigade on November 30, 1901. General Chaffee based his selection on Bell's superb performance in northern Luzon. The first month of General Bell's operations proved successful; this led him to expand the scope of his operations, and the last remaining insurgent commander General Miguel Malvar surrendered on April 13, 1902, ending the insurgency. Two and a half months later, on July 01, 1902, the United States Government formally took control of the Philippines. ${ }^{57}$

Analysts often attribute American success in the Philippine War to the effectiveness with which U.S. forces conducted stability tasks. ${ }^{58}$ A synthesis of the analysis highlights five areas that affected the U.S. military's conduct of stability operations in the Philippines, with four of them in a positive manner. First, U.S. Army officers expected to execute stability tasks because of officer development and prior organizational experience. Second, a comprehensive, centralized plan gave subordinate commanders intent and direction, but decentralized execution and latitude let each commander implement techniques based on their understanding of the situation within each district. Third, strategic objectives contained an element of stability, which permitted

\footnotetext{
${ }^{56}$ Ramsey, Savage Wars of Peace, 63, 79.

${ }^{57}$ Ibid., 102.

${ }^{58}$ Ramsey, Savage Wars of Peace, 113; Birtle, 100, 119; Linn, U.S. Army and Counterinsurgency in the Philippine War, 1899-1902, 163; Linn, The Philippine War, 1899-1902, 327. Ramsey suggested a policy of attraction was required in addition to a policy of coercion. Birtle wrote that "achieving a "convincing conquest' was only half the Army's strategy for winning the conflict." Political and economic affairs would play an important role in the final pacification. Linn claimed that decentralized counterinsurgency campaigns were the most effective at defeating guerillas. Such campaigns included offensive operations as well as civil affairs and reform projects. In The Philippine War, Linn further claimed the "crucial component of the American victory was civic action or social reform."
} 
commanders to develop holistic strategies to support achievement of those objectives. Fourth, key leaders in the Philippines grasped that simultaneous execution of stability tasks with offensive and defensive tasks provided a sound strategy to achieve benevolent assimilation. Fifth, civilmilitary cooperation created tension between military commanders and civilian authorities, but ensured unity of effort.

Institutional thinking formed through developmental experiences served as first factor that assisted in effective execution of stability operations. Execution of effective pacification techniques manifested itself in three ways during officer development. Military doctrine, officer education, and organizational experience (which included civil administration, policing, and reconstruction) all provided means that formulated how officers prepared for and executed operations. U.S. military commanders' foundational comprehension permitted them to develop strategies commensurate to the requirements in the Philippines and utilize modern stability tasks in the pacification of the Filipino insurrection. Their actions resulted in stabilization of the country and provided favorable conditions for long-term success. The development of officers in the 1890s through doctrine, education, and experience enabled commanders in the Philippines to develop well-informed, unconstrained, unbiased options to achieve strategic objectives.

Little published military doctrine existed at the time, and the few manuals that existed tended to focus on drill and infantry tactics. Two primary sources prescribed the conduct of operations, or what would equate to doctrine today: the 1892 Troops in Campaign: Regulations for the United States Army and General Order 100 issued in 1863, known as the Lieber Code. The 1892 regulations described the organization of the Army when called upon for service, quartermaster services, encampments, movement methods, and tactics in battle. ${ }^{59}$ The Lieber Code placed requirements and restrictions on military action during international occupation. The

\footnotetext{
${ }^{59}$ War Department, Troops in Campaign, 2-3.
} 
document included provisions to protect prisoners, prohibit actions such as torture, wanton destruction, and poisoning, and provide justification for specific action if the local population failed to adhere to the U.S. military's demands. ${ }^{60}$

Despite its somewhat limited coverage of stability tasks, the 1892 regulation did provide some guidance for pacification. The regulation called for a Provost Marshal attached to each headquarters. Their duties included protection of civilian inhabitants, an early requirement of current civil security tasks. ${ }^{61}$ In addition, Article VI discussed military occupation and requisitions in the enemy's territory. It identified military occupation and destruction of property as acceptable measures for securing objectives, ending the war, and protecting of lives of noncombatants. Military necessity permitted the destruction of property, the obstruction of ways of travel, and withholding of subsistence. ${ }^{62}$ Moreover, the regulation provided guidance on the characterization and handling of prisoners of war. It identified not only those directly engaged with arms against the United States, but also diplomatic agents or civil officers whose "services are important to the enemy." ${ }^{\prime 3}$ These articles offer an explanation for the reasoning behind some of Brigadier General Bell's more controversial operations. For example, Bell had the port cities closed, cutting off external support to the insurgents. This prevented the insurgents from obtaining arms and subsistence, a necessary measure for success - although its benefits came at the cost of various adverse effects on the neutral civilian populace. ${ }^{64}$

Similar to the regulations, students at the Infantry and Cavalry School studied the Lieber code. Developed by renowned professor and public scholar Francis Lieber in 1863 at the request

\footnotetext{
${ }^{60}$ Ramsey, A Masterpiece of Counterguerrilla Warfare, 16; Witt, 2.

${ }^{61}$ War Department, Troops in Campaign, 6.

${ }^{62}$ Ibid., 15.

${ }^{63}$ Ibid., 18.

${ }^{64}$ Ramsey, A Masterpiece of Counterguerrilla Warfare, 101.
} 
of President Abraham Lincoln's administration, General Order 100 governed the conduct of the Army during war. ${ }^{65}$ Derived partially from the limited international law that existed, the Army employed the code during the Civil War and Indian Wars. ${ }^{66}$ Officers such as Brigadier General Bell understood the document within the context of the time, both from academic study and practical application during his participation in the Indian War. When Francis Lieber's son Norman Lieber, a Judge Advocate General for the Department of the Philippines, reprinted and distributed the code, General MacArthur and Brigadier General Bell understood the requirements of the code and utilized it as their moral compass for determining strategy. ${ }^{67}$ It directed their actions pertaining to treatment of prisoners, administration of government through marital law, and protection of the population. ${ }^{68}$ To highlight the reliance on the document, General Bell issued thirty-eight circulars to subordinates describing actions for them to take and each one referenced General Order $100 .^{69}$

Related to the role limited doctrine played in officer development, the School of Application of Infantry and Cavalry at Fort Leavenworth, Kansas contributed to officer development in the late nineteenth century. The War Department directed the establishment of the school in General Order Number 42, issued in 1881 (the school opened on January 26, 1882). This order directed the school to provide practical instruction to officers in a range of topics including army organization, tactics, discipline, and care of men, horses, and property. The curriculum included both theoretical instruction, and opportunities to gain experience in the

\footnotetext{
${ }^{65}$ Witt, 229.

${ }^{66}$ Ibid., 181.

${ }^{67}$ Ibid., 356.

${ }^{68}$ Ibid., 375, 380, 383.

${ }^{69}$ Ramsey, A Masterpiece of Counterguerrilla Warfare, 14.
} 
science and practice of war. ${ }^{70}$ Reference material mentioned above dominated the curriculum, providing an in-depth understanding of approved methods for the conduct of operations as outlined in doctrine and policy. ${ }^{71}$

Two key individuals in particular benefited from association with and education at the Infantry school. Each was able to apply what they learned there during the Philippine War. First, the Adjutant General Brigadier General Richard C. Drum appointed then-Colonel Otis as commandant of the school upon its founding. ${ }^{72}$ Otis held this position for four years, which, given the mission of the school, enabled Brigadier General Otis to internalize the fundamental concepts underlying the application of United States doctrine and policy. Second, as a First Lieutenant, J. Franklin Bell posted to Fort Riley and subsequently joined the Cavalry with an assignment to the Infantry school. Bell attended the course, and after graduation remained there as a member of the faculty, where the commandant assigned him as the adjutant and later secretary to the commandant. During Bell's attendance as a student, the Army published the 1892 regulations. With the intense study and daily oral recitations, plus two additional assignments affording him even more time to study the regulations, Brigadier General Bell mastered the techniques identified in the regulation and adopted them as his guiding philosophy for conducting operations. $^{73}$

Organizational experience provided another source of officer development during the

\footnotetext{
${ }^{70}$ Elvid Hunt, History of Fort Leavenworth 1827-1937. (Fort Leavenworth: Command and General Staff School Press, 1937), 163.

${ }^{71}$ Birtle, 101.

${ }^{72}$ Hunt, 162.

${ }^{73}$ Elwell S. Otis, 1883 Infantry and Cavalry School Annual Report (Fort Leavenworth, KS: Combined Arms Research Library, 1883), http://usacac.army.mil/cac2/cgsc/carl/download/reports/ rep1883.pdf (accessed December 16, 2013). In his annual report to the Secretary of War, COL Otis described the intense preparations and numerous individual recitations of material. Successful recitations were a graduation requirement, with those unable to complete this requirement either dismissed from the school or made to repeat the academic year.
} 
period prior to the Philippine War. While this experience included little participation in combat that occurred on a very small scale, it created a sizable and diverse pool of officers. After the Civil War, the government reduced the size of the military dramatically by demobilizing the volunteer army. ${ }^{74}$ With no existential threat to focus on, the Army turned its attention to a variety of missions. Among these, the Army practiced civil administration, playing a principal role in reconstruction after the Civil War. The Army continued its civil administration function for over a decade as the collapse of various local government organizations during the war delayed reconstruction in the South. The Army performed tasks including the regulation of commercial law, public education, overseeing elections and voter registration, and approval of state constitutions. $^{75}$

The Army also performed duties normally associated with a police force. During the reconstruction era, the lack of effective police led the Army to deal with criminal activity like horse stealing and moonshining. The government also called upon the Army to suppress Ku Klux Klan terrorist acts. After reconstruction officially ended in 1876, the Army continued its policing functions and dealt with domestic disturbances around the country, such as the federal riots of 1877. During this crisis, the Army restored order in major cities and put down the strikes without the loss of a single life. In 1894, the United States Government called on the Army once again to enforce United States law and judicial process during the Pullman strike. The Army rose to the challenge, successfully quelling the riot with only one fatality despite facing thousands of mobincited rioters. $^{76}$

During this period the Army also devoted significant effort to public works

\footnotetext{
${ }^{74}$ Matloff, 281.

${ }^{75}$ Ibid., 284.

${ }^{76}$ Ibid., 286.
} 
administration. After the United States purchased Alaska in 1867, the Army led all civil matters within the state other than commerce and navigation. Similar to its responsibilities after the Civil War, the Army governed the state for a decade, at which point it passed responsibility to the Treasury Department to focus on exploratory expeditions. ${ }^{77}$ On the continental United States, the Army also increased the construction of public buildings and expanded the Corps of Engineer program nation-wide. Waterworks and vertical construction efforts increased engineering expertise within the Army, while honing its skill at integrating with civil authorities. ${ }^{78}$

Pertaining to combat, few officers still serving in the late 1890s had fought in the Civil War. Their experience of combat consisted almost solely of participation in the Indian Wars. ${ }^{79}$ Having fought the Indians for the better part of a century, interrupted only briefly by the Civil War, the United States government had learned that it could not defeat the Indians through combat operations alone. In the late 1860s, official government policy changed from removing Indians to concentrating them on reservations. Most of the remaining Indian populations resisted this policy as well, resulting in over a thousand skirmishes of various sizes and across a wide portion of the American frontier - from the Southwest to the Northern Plains to the Pacific Northwest. The Indian Wars lasted twenty years, finally culminating in 1890 after the Battle of Wounded Knee. After the battle the government successfully confined the remaining Indian tribes to reservations and the Army returned to constabulary duties along the frontier. ${ }^{80}$ These limited warfare engagements consumed the attention of the Army while conventional battle and tactics remained the focus of educational institutions such as the School of Application for Infantry and Cavalry at Fort Leavenworth, the Engineer School of Application at West Point, and the Artillery

\footnotetext{
${ }^{77}$ Matloff, 296.

${ }^{78}$ Ibid., 297.

${ }^{79}$ Ibid., 300.

${ }^{80}$ Ibid., 300-318.
} 
School at Fort Monroe. ${ }^{81}$ These schools ensured the military maintained at least a theoretical understanding of conventional warfare within its institutional knowledge, augmenting real-world experience of a wider range of operations.

The existence of a comprehensive, centralized plan of operations in the Philippines also contributed to the successful execution of stability tasks. The campaign achieved mixed results because of various factors such as the character of the military officers within each district and their understanding, or lack thereof, of the nature of the insurgency. Despite local variances, however, success stemmed largely from the existence of one central strategy, combined with the latitude Otis and MacArthur gave subordinate commanders for decentralized execution of the strategy. ${ }^{82}$ Major General Otis focused primarily on civil aspects for pacification during his time in command. For example, he issued General Orders 40 and 43, directing subordinates across the Philippines to establish local governments ${ }^{83}$ Each commander complied, but to different degrees. Some established puppet governments while keeping the military firmly in control, while others handed authority over to Filipino civilians ${ }^{84}$ After Major General MacArthur assumed command, he implemented more stringent rules for dealing with the populace and developed a harsher plan of campaign, actions supported by the declaration of martial law and the issuance of General Order $100 .{ }^{85}$ Again, each subordinate commander had the leeway to adapt the strategy to the circumstances present within his district. Nevertheless, MacArthur expected each commander to

\footnotetext{
${ }^{81}$ Matloff, 289; Birtle, 101.

${ }^{82}$ Linn, U.S. Army and Counterinsurgency in the Philippine War, 1899-1902, 22.

${ }^{83}$ Ramsey, Savage Wars of Peace, 22.

${ }^{84}$ Linn, U.S. Army and Counterinsurgency in the Philippine War, 1899-1900, 50, 108.

${ }^{85}$ Ramsey, Savage Wars of Peace, 114; Birtle, 128-30.
} 
follow the intent of the overarching strategy. ${ }^{86}$

A clearly articulated strategic objective, the third factor that accounted for stability and long-term success, served as an essential ingredient of the American victory. President McKinley issued a series of messages that provided clear strategic guidance and objectives for the campaign in the Philippines. McKinley addressed the first such message to the Secretary of War regarding benevolent assimilation. In the document, McKinley issued the directive that the "mission of the United States is one of benevolent assimilation." ${ }^{87}$ To achieve this, "the occupation and administration of the ... Philippines Islands becomes immediately necessary." ${ }^{88}$ Further, it fell to the military to see that "all ports and places ... be opened to the commerce of all friendly nations. ${ }^{" 89}$ Requiring not just the occupation but also the administration of the Philippines and facilitation of commerce provided clear strategic objectives that contained an element of stability.

A second message issued January 20, 1899 to the Secretary of State directed that the military authorities in the Philippines assume responsibility for "the temporary government of the islands." ${ }^{\circ 0}$ The message clearly indicated an expectation for the military to conduct stability operations in fulfilling this role. A third directive issued on May 19, 1898 to General Wesley Merritt through the Secretary of War dictated, "Though the powers of the military occupant are absolute ... the municipal laws of the conquered territory are continuing in force." ${ }^{91}$ In addition to defeating the insurgency, the military was to give top priority to establishing a new political

\footnotetext{
${ }^{86}$ Ramsey, Savage Wars of Peace, 117-9.

${ }^{87}$ Linn, "War Termination,” 133; Richardson, 220.

${ }^{88}$ Ramsey, Savage Wars of Peace, 13.

${ }^{89}$ Richardson, 211

${ }^{90}$ Ibid., 223.

${ }^{91}$ Ibid., 209
} 
power, protect inhabitants and their property, and open ports to resume trade. ${ }^{92}$ The emphasis in this directive on the military responsibility for enforcement of the rule of law, and establishment of political and economic institutions, described strategic objectives that modern U.S. military doctrine would categorize as stability tasks and operations. The directive contained clear political and economic objectives for Merritt to achieve. Such messages specifically addressed the stability aspect of the conflict, which permitted military commanders to develop a strategy aimed not only at the defeat of Emilio Aguinaldo's guerrilla forces, but also at the pacification of the population and establishment of American dominance.

Also contributing to the effective execution of stability tasks, U.S. forces simultaneously executed offensive, defensive, and stability tasks throughout the duration of the occupation. Major General Otis, serving as the VIII Corps commander and first Army commander in the Philippines after hostilities began, understood the strategic objectives and envisioned requirements after major combat operations to ensure a stable environment. Upon his arrival in the Philippines in October 1898 , he set in motion a military strategy to develop the capacity of local governments and police. He sought to hold public elections as another method to instill legitimacy and pacify the population. As the conventional fight occurred between Major General Otis’ American forces and Emilio Aguinaldo's Army of Liberation, Major General Otis continued to pursue stability objectives that would promote security and maintenance of United States national interests. ${ }^{93}$ To ensure the effectiveness of these elements of his strategy, Otis conferred with Dr. Jacob Schurman, director of McKinley's first Philippine Commission, and recruited leaders that were sympathetic to American rule. He then issued General Order 43, directing subordinates to establish local governments to compliment his counter-guerrilla

\footnotetext{
${ }^{92}$ Richardson, 210; Linn, The Philippine War, 1899-1902, 6.

${ }^{93}$ Ramsey, Savage Wars of Peace, 17-8.
} 
efforts. ${ }^{94}$ Although he tendered his resignation shortly thereafter, his recognition for requirements other than offensive and defensive tasks charted the course for the Philippine campaign.

Otis' successor Major General Arthur MacArthur followed suit, providing guidance to subordinate commanders to divide their efforts equally between pacifying the population and conducting combat operations against the enemy. During his first year in command, MacArthur's subordinates proved reluctant to follow this guidance, preferring to focus on defeat of insurgents rather than conducting pacification efforts. This intense focus on, and mounting frustration with, guerrilla fighters led U.S. Army personnel to commit numerous atrocities against Filipinos. ${ }^{95}$ MacArthur's pacification strategy did not come to fruition until Bell's transfer and skillful conduct of operations in southern Luzon. ${ }^{96}$

As commander of the 3d Separate Brigade in Southern Luzon, Brigadier General Bell developed successful methods to synchronize what the U.S. Army now calls offensive, defensive, and stability tasks. Brigadier General Bell established zones of protection to isolate the population from the insurgents. He then conducted simultaneous offensive operations and stability tasks to maximize their effects, while maintaining defensive positions around the zones of protection. For example, Bell conducted offensive operations during the first two weeks of January 1902, clearing Batangas and Tayabas provinces and defeating the insurgents. ${ }^{97}$ At the same time, Bell ordered his Provost Marshal to conduct policing functions across the three provinces. Knowing that the elites played a major role in enabling the insurgency, he arrested local elites who did not

\footnotetext{
${ }^{94}$ Linn, U.S. Army and Counterinsurgency in the Philippine War, 1899-1902, 21;Ramsey, Savage Wars of Peace, 19.

${ }^{95}$ Ramsey, A Masterpiece of Counterguerrilla Warfare, 95; John M. Gates, The U.S. Army and Irregular Warfare (Wooster: College of Wooster, 2002), Chapter V, 3, http://www3.wooster.edu/history/ jgates/pdfs/fullbook.pdf, 3-5 (accessed December 12, 2013).

${ }^{96}$ Ramsey, A Masterpiece of Counterguerrilla Warfare, 119.

${ }^{97}$ Ibid., 100.
} 
publicly support the United States under provisions outlined in General Order 100. ${ }^{98}$ These policing functions served as civil control, one of today's stability tasks and isolated insurgents from their support group. Additionally, Bell implemented an immunization program within the zones of protection and directed subordinates to build storehouses, establish fair markets, and conduct public work projects. ${ }^{99}$ These tasks, when framed in today's stability lexicon of support to economic and infrastructure development, aimed to win popular support of the Filipinos. ${ }^{100}$ The multi-faceted strategy Bell adopted led to the pacification of the population and ultimately a successful end to the war.

Finally, a consistent focus on civil-military cooperation contributed to the success of U.S. military stability efforts, although relationships and tensions limited the effectiveness of civilmilitary cooperation. President McKinley appointed both Major General Otis and MacArthur the commander of military forces and the military governor. ${ }^{101}$ The dual role of Governor-General contributed to the tensions between the military commanders and the two separate commissions sent by President McKinley.

In 1899, President McKinley sent Dr. Jacob Schurman to assist Major General Otis in assessing Filipino attitudes toward American authority. Otis felt that Schurman impeded on his territory and mission, and therefore he marginalized the Commission's efforts. ${ }^{102}$ However, after dialogue with Schurman and the departure of the first commission, Otis recruited pro-American

\footnotetext{
${ }^{98}$ Linn, U.S. Army and Counterinsurgency in the Philippine War, 1899-1902, 153.

${ }^{99}$ Ibid., 154.

${ }^{100}$ Headquarters, Department of the Army, ADRP 3-07, 2-18.

${ }^{101}$ Linn, "War Termination," 148.

${ }^{102}$ Linn, The Philippine War, 1899-1902, 91.
} 
Filipinos for office and issued General Order 43 for the establishment of local governments. ${ }^{103}$ Then, after Otis' resignation, Major General Arthur MacArthur assumed command and McKinley sent William Howard Taft to the Philippines. Taft's charter was to negotiate and facilitate the "most humane, pacific, and effective extension of authority ... and to secure the benefits of protection" for the Filipino population. ${ }^{104}$ As the Governor-General, MacArthur employed Taft as more of an advisor than the head of the second Presidential Philippine Commission responsible for the transition from the military government. MacArthur was proud of the military's accomplishments and could not accept subordination to civilian authority. ${ }^{105}$ This tension made unity of effort difficult to achieve and lasted the remainder of the war, but civil-military cooperation still existed as a result of national policy and the actions of presidential appointees. This cooperation contributed to the overall success of the campaign.

United States success in the Philippines did not only come from harsh measures. While today's U.S. public might not accept some of the actions undertaken by American military forces at the time, the important lesson lies in the fact that the U.S. government and Army planned for and conducted stability operations from the start. By examining the planning and execution of the war through the lens of the five factors described above, one can see the reason for the effectiveness of stability operations in the Philippines. U.S. Army officers expected to execute stability tasks because of institutional thinking formed through officer development and prior organizational experience; they followed a comprehensive, centralized strategy coupled with decentralized execution; this strategy included stability considerations in strategic and military objectives; key leaders in the Philippines understood the need to simultaneously conduct stability

\footnotetext{
${ }^{103}$ Ramsey, Savage Wars of Peace, 17-8.

${ }^{104}$ Ramsey, A Masterpiece of Counterguerrilla Warfare, 17.

${ }^{105}$ Linn, The Philippine War, 1899-1902, 216.
} 
tasks with offensive and defensive tasks; and tenuous efforts towards civil-military cooperation hindered unity of effort but still contributed to success. The incorporation of stability tasks greatly assisted in American success during the Philippine War; and the factors that enhanced effectiveness with which U.S. forces conducted stability tasks ultimately achieving America's strategic aims.

\section{Panama and Operations Just Cause and Promote Liberty}

Panama has historically been a key ally of the United States since 1903. The United States views Panama as vital to U.S. interests due to the significance of the Panama Canal for the efficiency of intercontinental commerce. ${ }^{106}$ Beginning in 1987, favorable relations with Panama, specifically Manuel Noriega's government, began to collapse. Months of harassment of U.S. military personnel stationed in Panama, as well as accusations against Noriega (made by both American and Panamanian leaders) for murder, drug trafficking, and election fraud contributed to this disintegration. In February 1988, two U.S. federal grand juries indicted Noriega on a number of criminal charges, resulting in a sharp increase in harassment of U.S. military personnel stationed in Panama as retribution.

From February through December 1988, over 300 incidents of harassment, threats, or assaults took place. ${ }^{107}$ This trend continued into 1989 , including two particularly serious incidents. One involved the detainment of U.S. Naval personnel, and the other related to the Panamanian Defense Forces' (PDF) seizure of a school bus transporting U.S. children. On December 16, 1989, an off-duty military officer was shot and killed during a traffic stop, and the PDF detained two eyewitnesses of the event. President George H. W. Bush authorized military

\footnotetext{
${ }^{106}$ Matloff, 353.

${ }^{107}$ R. Cody Phillips, Operation Just Cause: the Incursion Into Panama (Washington, DC: Center of Military History, 1991), 8.
} 
intervention after this incident to safeguard the lives of Americans, to defend democracy in Panama, and to protect the integrity of the Panama Canal Treaty. Four days later, on the morning of December 20, 1989, the United States invaded Panama with the additional mission of removing Noriega from power and extraditing him to the United States. ${ }^{108}$

Upon execution, Operation Just Cause (originally named Blue Spoon) lasted just under a month. U.S. forces captured Noriega and on January 12, 1990, Just Cause ended and left Operation Promote Liberty as the only American operation in effect. Promote Liberty (originally named Kristal Ball, then Blind Logic), was the post-combat operation employing civilian and military organizations. It aimed to restore stability in the country. Due to the rapid buildup of combat power disguised training exercises in Panama, and detailed and intense planning efforts, the invasion was a complete success. ${ }^{109}$ However, the failure to account for post-combat activities or execute stability tasks as simultaneous activities during major combat operations nearly derailed the initial successes of the invasion.

Analysts often consider the invasion of Panama a resounding success. A closer look at the analysis provided by numerous authors suggests that this success entails only the initial invasion and first six days of operations in Panama - not the entire process from planning through stabilization operations. ${ }^{110}$ An evaluation of planning and post-combat operations suggests a more tempered proclamation of success summarized by five key factors. First, institutional thinking, developed through organizational experience, U.S. national policy, and U.S. Army doctrine,

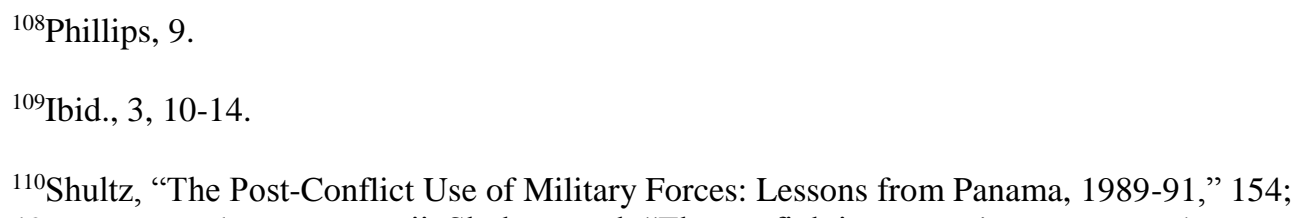

${ }^{110}$ Shultz, "The Post-Conflict Use of Military Forces: Lessons from Panama, 1989-91,” 154; Phillips, 42; Watson and Tsouras, x-xii. Shultz stated, "The warfighting operation appears to have gone extremely well. The same cannot be said for 'Blind Logic'." Phillips stated the incursion was initially successful, but the post-combat tasks required of military forces presented challenges that they were initially unprepared to execute. Watson and Tsouras claimed Just Cause was full of successes from joint operations to command and control. Contrast this to Promote Liberty where, while ultimately successful, civil affairs operations proved to have more weaknesses than strengths. 
limited the Army's ability to prepare adequately for conflicts other than large-scale conventional war. Second, two separate organizations conducted operational planning for the conflict and developed two separate plans, one for the invasion and another for the stabilization of Panama. Third, military objectives did not nest clearly with strategic objectives, in particular by omitting stability elements. Neglecting stability as an objective reinforced the military's perception that another organization would conduct post-combat tasks. Fourth, key leaders in Panama did not emphasize that simultaneous execution of stability tasks provided a sound strategy for security that would assist post-combat stabilization efforts. Fifth, civil-military cooperation achieved mixed results. The Army compartmentalized pre-combat planning, excluding civilian agencies from participation. ${ }^{111}$ However, after the initial invasion ended, civil-military cooperation increased along with interaction with the GOP, becoming very effective.

Institutional thinking - particularly organizational experience, policy, and doctrine limited the effectiveness of stability operations in Panama. Twenty years prior to its participation in Operation Just Cause, the Army remained deeply embroiled in the Vietnam War. Following the military's morale-crushing withdrawal from Vietnam in 1973, senior leaders sought to rejuvenate its spirit partly by refocusing military doctrine and training on the possibility of a major conflict with the Soviet Union in Eastern Europe and Germany. This led to the creation of Training and Doctrine Command (TRADOC) in 1973, which began a major effort to rewrite Army doctrine and guide the Army's procurement programs to buy the conventional weapons deemed necessary to fight mechanized combined arms warfare in open terrain. ${ }^{12}$ TRADOC's revision of the Army's operations manual, FM 100-5, led to the implementation of active defense doctrine. While this doctrine evolved over time to Air Land Battle doctrine, the Army remained focused on

\footnotetext{
${ }^{111}$ Shultz, “The Post-Conflict Use of Military Forces: Lessons from Panama, 1989-91,” 150.

${ }^{112}$ Benjamin King, Victory Starts Here: A 35-Year History of U.S. Army Training and Doctrine Command (Fort Leavenworth, KS: Combat Studies Institute Press, 2008), v.
} 
the threat of a massive eastern European war for the next fifteen years. ${ }^{113}$

In addition to preparing for war with the Soviet Union, the Army participated in a variety of limited engagements around the globe during the same twenty years, including Cyprus in 1974, the Sinai in 1981, Lebanon and Grenada in 1983, Nicaragua in 1984, Bolivia and Libya in 1986, Honduras in 1988, and the U.S. Virgin Islands in 1989. In addition to these overt operations, the Army supported several covert operations as the U.S. government sought to avoid the perception that it might engage in another Vietnam-like war. These include Angola in 1975, Iran in 1979, Afghanistan in the 1980s, and Israel in 1982. ${ }^{114}$

These post-Vietnam experiences ran counter to institutional culture and thought regarding the supposed primacy of large-scale conventional war. This prevented many policymakers and military leaders from recognizing the fact that the operational environment differed from that prescribed by National Security Strategy and U.S. Army doctrine. This misinterpretation of the operational environment - one characterized by large-scale conventional combat rather than one primarily involving limited warfare - limited the military's ability to optimize institutional thought and capabilities to match the true requirement for military forces. Given the number of small-scale incursions the Army participated in versus the level of effort it expended preparing for the large-scale conflict that never occurred, one wonders how leaders failed to account for the difference between national policy, strategy, and military doctrine, and the indicators and actions of reality through the decade. It seems that after a decade in which the U.S. government remained focused on the larger existential threat of the Soviet Union rather than the many limited war interventions that solidified the United States' position in the international order, leaders should

\footnotetext{
${ }^{113}$ John L. Romjue, Susan Canedy, and Anne W. Chapman, Prepare the Army for War: A Historical Overview of the Army Training and Doctrine Command, 1973-1993, TRADOC Historical Studies (Fort Monroe, VA: Office of the Command Historian, United States Army Training and Doctrine Command, 1993), 54.

${ }^{114}$ Herring, 816, 824, 872, 877, 888, 891
} 
have recognized this shortcoming and adjusted the foundational documents accordingly.

It seems odd that Army leaders did not tailor Army doctrine to fit the real world threat rather than the focus of United States policy. By maintaining two-way dialogue and promoting change from below, institutional thought would adjust and increase its preparedness to conduct stability operations. The rationale rests on the basic principle that policy informs doctrine. During the 1980s, the United States was fully entrenched in the Cold War with the Soviet Union. Entering its fourth decade with no apparent end in sight, foreign policy and Nation Security Strategy focused on negating communist tyranny and defeat of the Soviet Union should conflict break out. ${ }^{115}$ Events like the United States' involvement in the Korean War in the early 1950 s, the Cuban missile crisis of 1962-3, the involvement in African affairs during the mid-1970s, and involvement in Afghanistan during the early 1980s reinforced the tendency to focus on the Soviet threat. ${ }^{116}$

President Ronald Reagan continued the focus during his first term, bringing tensions to an all-time high between the two superpowers. This focus remained despite an increase in global terrorism, as exemplified by Arab-Israeli conflict, Libyan terrorist attacks in Germany and Italy, the rise of the Palestinian Liberation Organization (PLO), and proxy wars in the Congo and Angola. The Reagan administration's policy illustrated a general reluctance to acknowledge regional conflicts and, in particular, get involved in another war like that in Vietnam through documents such as the national security strategy. In the 1987 NSS, President Reagan identified the global challenge posed by the Soviet Union as the most significant threat to the United States' security interests. ${ }^{117}$ Further, out of the two pages of text outlining principal threats to U.S.

\footnotetext{
${ }^{115}$ Herring, 863.

${ }^{116}$ Ibid., 635-42, 720-4, 843-4, 852-4.

${ }^{117}$ White House, National Security Strategy (1987), 6.
} 
interests, only two small paragraphs referred to threats other than the Soviet Union. President Reagan dedicated one paragraph to non-communist nations with oppressive governments and the second merely mentions proliferation of international terrorism. ${ }^{118}$ To emphasize the threat posed by the Soviet Union while dismissing the significance of limited war, he repeated those words verbatim in the 1988 NSS. ${ }^{119}$

Reagan's Soviet Union-focused foreign policy influenced the way the Pentagon addressed real or potential crises through doctrine and force structure. ${ }^{120}$ Military doctrine of the 1980s nested well with the National Security Strategy, with its focus on major conventional war against the Soviet Union, potentially involving weapons of mass destruction. This doctrine also fit within the overall national narrative that sought to purge the memory of the United States' defeat in Vietnam. Military thinking dismissed limited warfare and reinforced the significance of Clausewitzian total war and the decisive engagement. In the Army's capstone operations doctrine, a majority of the text prescribed the method in which the Army would fight a major war with the Soviet Union. ${ }^{121}$ FM 100-5: Operations dedicated barely one-half of a page out of its 187 pages to LIC. ${ }^{122}$ The Army claimed the tenets covered in Air Land Battle applied equally to LIC, but transferred discussion of limited warfare to FM 100-20: Low Intensity Conflict and identified Special Forces as the proponent for those types of missions. ${ }^{123}$ One year after the Army published

\footnotetext{
${ }^{118}$ White House, National Security Strategy (1987), 7.

${ }^{119}$ White House, National Security Strategy (Washington, DC: The White House, 1988), 5.

${ }^{120}$ Yates, The U.S. Military Intervention in Panama, 33.

${ }^{121}$ Headquarters, Department of the Army, FM 100-5 (1986), i. The preface included a broad assertion that FM 100-5, as the Army's keystone warfighting manual, explained how Army forces planned and conducted campaigns, major operations, battles, and engagements, with an emphasis on major conventional military operations that supported NATO's forward defense plan. The defense plan supported Allied Tactical Publication 35A against the Soviet Union and its surrogates.

${ }^{122}$ Headquarters, Department of the Army, FM 100-5 (1986), 4.

${ }^{123}$ Headquarters, Department of the Army, FM 100-5 (1986), 6; Headquarters, Department of the
} 
Air Land Battle, U.S. Secretary of Defense Caspar Weinberger outlined six specific points that he believed should guide both the decision to use military power, and the manner in which to use it. At a speech given at the National Press Club, he enumerated his proposed guidelines for military intervention:

1. The United States should not commit forces to combat overseas unless the particular engagement or occasion is deemed vital to our national interest or that of our allies.

2. If we decide it is necessary to put combat troops into a given situation, we should do so wholeheartedly, and with the clear intention of winning. If we are unwilling to commit the forces or resources necessary to achieve our objectives, we should not commit them at all.

3. If we do decide to commit forces to combat overseas, we should have clearly defined political and military objectives. And we should know precisely how our forces can accomplish those clearly defined objectives.

4. The relationship between our objectives and the forces we have committed -their size, composition and disposition -- must be continually reassessed and adjusted if necessary.

5. Before the U.S. commits combat forces abroad, there must be some reasonable assurance we will have the support of the American people and their elected representatives in Congress.

6. The commitment of U.S. forces to combat should be a last resort. ${ }^{124}$

Army, Field Manual 100-20: Low Intensity Conflict (Washington, DC 1986), 5-19.

${ }^{124}$ Caspar W. Weinberger, "The Uses of Military Power" (speech, National Press Club, Washington, DC, November 28, 1984), http://www.pbs.org/wgbh/pages/frontline/shows/military/ force/weinberger.html (accessed December 29, 2013). 
Weinberger promoted an implied message along with the six explicit points that he identified: when the nation called upon the military to fight, it must know exactly what military force should achieve, the nation should commit nothing short of overwhelming force, and it should employ troops only for short duration missions. President Reagan reiterated Weinberger's guidelines in his National Security Directive Decision 238 issued September 2, 1986. In it, President Reagan wrote that the United States would avoid committing forces to conflicts that did not involve the Soviet Union whenever possible. If the U.S. government did commit combat troops to achieve political objectives, the president asserted that the U.S. government would limit the duration of the mission by committing adequate forces to ensure they could achieve their objectives as quickly as possible. ${ }^{125}$

Despite Reagan's support, Weinberger's strategic guidelines for the use of military force did meet some resistance. Weinberger's colleague Secretary of State George Shultz disputed Weinberger's points, noting that such a policy impacted American diplomacy by limiting the nation's ability to employ military force in 'limited' wars. ${ }^{126}$ As Secretary Schultz noted, such a policy created an aversion to LIC within the military and reinforced the concept of Air Land Battle. Demonstrating Schultz's point, the U.S. military's intervention in Panama exemplified the Weinberger doctrine in its deployment of overwhelming force. Twenty-six thousand U.S. troops deployed on the evening of December 20, 1989 against the PDF of just over eight thousand personnel, accomplished their objectives and began redeployment within fourteen days of the initial invasion, and completed redeployment after only twenty days. ${ }^{127}$ 1986), 16.

${ }^{125}$ White House, National Security Decision Directive 238. (Washington, DC: The White House,

${ }^{126}$ Jim Mokhiber and Rick Young, "The Uses of Military Force," http://www.pbs.org/wgbh/ pages/frontline/shows/military/force (accessed December 29, 2013).

${ }^{127}$ Ronald H. Cole, Operation Just Cause: the Planning and Execution of Joint Operations in Panama, February 1988-January 1990 (Washington, DC: Joint History Office, Office of the Chairman of 
The three areas of organizational experience, policy, and doctrine formed institutional thinking regarding military conflict during the 1980s. From those areas, institutional thinking considered stability and LIC much lower in status than conventional combat and as such, the Army did not adequately prepare for these types of tasks and operations. ${ }^{128}$ This had a negative impact on the effectiveness of stability tasks in operations such as Just Cause.

The ineffective execution of stability tasks in Panama also occurred as a result of the development of two distinct plans by two separate headquarters. The first plan, Just Cause, dealt with the actual invasion and regime change. This plan received a preponderance of the commander's attention. The second plan, Promote Liberty, pertained to stability operations. With the two separate plans created by two separate headquarters, the staffs did not adequately synchronize stability tasks with offensive tasks.

General Maxwell Thurman, who became Commander-in-Chief-United States Southern Command (CINC-USSOUTHCOM) four months before the invasion, summed up the pitfall in separating the two plans when interviewed after the conflict. He admitted that during his in-briefs as the newly appointed commander, Thurman spent no more than five minutes reviewing the Blind Logic (Promote Liberty) plan. ${ }^{129}$ Compounding the problem, when the XVIII Airborne Corps assumed lead headquarters responsibility as Joint Task Force-Panama, USSOUTHCOM only passed Blue Spoon (Just Cause) to the XVIII Airborne Corps staff; Blind Logic remained with the USSOUTHCOM J-5 for planning. ${ }^{130}$ This created a perception that Lieutenant General Carl Stiner, the XVIII Airborne Corps Commander, had no responsibility for stability planning or

the Joint Chiefs of Staff, 1995), 68; Phillips, 10.

${ }^{128}$ Shultz, In the Aftermath of War, 20.

${ }^{129}$ Shultz, In the Aftermath of War, 16; Yates, The U.S. Military Intervention in Panama, 269; Craig I. Fields and Philip A. Odeen, Transition to and from Hostilities Volume II (Washington, DC: Defense Science Board, January 2005),10; Fishel, The Fog of Peace, 25.

${ }^{130}$ Yates, The U.S. Military Intervention in Panama, 156, 269. 
execution. All involved arrived at the natural conclusion that some other organization would plan and conduct post-combat operations. ${ }^{131}$

One can see the evidence of this thinking clearly when comparing the strategic and military objectives. XVIII Airborne Corps focused on termination, while neglecting matters associated with post-combat restoration. ${ }^{132}$ The military's assumption that another governmental organization would sweep in and conduct stabilization equated to wishing away a major risk one that led to a deteriorated security situation because of the lack of planning or mitigation. The military could have planned adequately for such a scenario and anticipated the disorder and chaos that the removal of Noriega would create if one headquarters had synchronized planning for both aspects of the mission. Instead, separation of the plans created much confusion, including the failure to identify exactly what headquarters would execute post-conflict restoration and under what command authority. ${ }^{133}$ The USSOUTHCOM J-3 developed the Blue Spoon plan, while the J-5 developed Kristal Ball (Promote Liberty). XVIII Airborne Corps inherited Blue Spoon, but when the time came to execute Promote Liberty on December 22, 1989, General Thurman put the $\mathrm{J}-5$ in charge of execution. However, the J-5 does not have command authority so this left command relationships unclear, and the J-5 continued to report to USSOUTHCOM rather than JTF-PM.

Disconnected strategic and military objectives reinforced perceptions that the military had no role in the conduct of stability operations. President Bush identified four strategic objectives for the intervention in Panama: (1) to protect American lives, (2) to protect American

\footnotetext{
${ }^{131}$ Shultz, “The Post-Conflict Use of Military Forces: Lessons from Panama, 1989-91,” 151; Fishel, The Fog of Peace, 26. and Odeen, 10.

${ }^{132}$ Shultz, "The Post-Conflict Use of Military Forces: Lessons from Panama, 1989-91," 150; Fields

${ }^{133}$ Shultz, In the Aftermath of War, 22; Shultz, "The Post-Conflict Use of Military Forces: Lessons from Panama, 1989-91," 152.
} 
interests, (3) to restore Panamanian democracy, and (4) to apprehend Noriega. The strategic objectives may not have been completely clear and articulate, but they were broad and multidimensional. They provided the military latitude to develop objectives and a strategy that would accomplish the four strategic objectives. However, the military missed an opportunity to capitalize on this freedom of action and restricted its objectives only to those with a security focus. ${ }^{134}$ Comparison of the strategic objectives with the operational objectives General Stiner developed for Just Cause reveals the fact that he omitted any reference to stability, instead concentrating solely on three combat-oriented objectives: (1) destroy the combat capability of the Panamanian Defense Forces, (2) seize facilities essential to the operation of the Panama Canal, and (3) apprehend Noriega and rescue prisoners held by him. ${ }^{135}$

Military planners also neglected to synchronize stability tasks with offensive tasks during the first part of the invasion. As mentioned previously, military leaders paid little attention to civil affairs. For example, the lack of emphasis on stability led to the decision to deploy the first Civil Affairs personnel to Panama six days after the invasion began. ${ }^{136}$ These individual volunteers deployed piecemeal via Military Airlift Command flights and assumed duties in the CMOTF as they arrived in country in this haphazard manner. ${ }^{137}$ The next group of Civil Affairs personnel, assigned to lower echelon units, arrived three weeks later on January $17,1990 .{ }^{138}$ The late arrival of the civil affairs team demonstrated that commanders did not intend to execute stability tasks simultaneously with offensive tasks.

Further, General Thurman initiated Promote Liberty on December 22, 1989, but did not

\footnotetext{
${ }^{134}$ Shultz, In the Aftermath of War, xi, 19; Watson and Tsouras, eds., 69.

${ }^{135}$ Watson and Tsouras, eds., 69.

${ }^{136}$ Ibid., 127.

${ }^{137}$ Shultz, In the Aftermath of War, 31 .

${ }^{138}$ Ibid., 129.
} 
place General Stiner in charge of the operation from the beginning. By executing a synchronized offense and stability plan from the beginning of the invasion, the United States could have corrected the mistake of separating the two plans. However, rather than giving JTF-PM responsibility at the beginning of Operation Promote Liberty, Thurman directed Brigadier General Benard Gann, USSOUTHCOM J-5, to lead the CMOTF. ${ }^{139}$ This created a second headquarters with command authority conducting integrated missions within the same area of operations.

The Army also showed little interest in performing policing functions, for which staffs also did not plan adequately. After the military captured Noriega and disbanded the PDF, a lapse of security resulted in chaos, mass rioting, and looting. The result of this looting (which the military forces involved in the operation could have easily prevented through training for and shifting to a policing function) cost an estimated \$2 billion dollars in damage and stolen property. ${ }^{140}$ Given hindsight, the absence of rule of law resulted in mass rioting and financial disaster - a glaring example of a missed opportunity to stabilize an economy shocked by the regime change. Nevertheless, conventional army units would likely have lacked adequate preparation to conduct policing functions even if tasked to perform them. Light infantry units claimed to be LIC-oriented, but all their training focused on Air Land Battle doctrine, which saw LIC as a simpler subset of conventional combat rather than a unique form of warfare. ${ }^{141} \mathrm{With}$ the massive conventional war focus, tactical-level commanders felt it was difficult to turn the infantryman into a constable, particularly so quickly after hostilities. ${ }^{142}$ When USSOUTHCOM

\footnotetext{
${ }^{139}$ Fishel, The Fog of Peace, 32.

${ }^{140}$ Shultz, In the Aftermath of War, 28.

${ }^{141}$ Yates, The U.S. Military Intervention in Panama, 35; Shultz, In the Aftermath of War, 18.

${ }^{142}$ Clarence E. Briggs III, Operation Just Cause a Soldier's Eyewitness Account: Panama, December 1989 (Harrisburg, PA: Stackpole Books, 1990), 94.
} 
tasked JTF-PM to conduct policing functions for security purposes, many junior officers and noncommissioned officers felt their units lacked adequate training to perform policing duties, and believed that their roles did not include acting as police officers. ${ }^{143}$ Security eventually fell to the Military Support Group (MSG), created a month after the invasion on January 17, 1990. With limited military police available, the MSG relied on a DOS program to train security personnel. ${ }^{144}$

The lack of emphasis on stability during execution traced back directly to oversight during planning. Staff officers did form adequate or realistic estimates of relief efforts the mission would involve or the resources they would require. The United States took responsibility for only 3,000 of the more than 15,000 displaced persons. ${ }^{145}$ The remainder went without sufficient food or shelter, and suffered from post-traumatic stress, injuries, and communicable diseases. USAID did provide cots, blankets, and one meal per day - one additional meal coming from private donations - although the planners forecasted sufficient supplies for only 2,200 persons. Besides arriving in insufficient quantities, the humanitarian relief supplies remained unavailable for several days after the invasion, resulting in many sleeping outside despite intermittent rainy conditions. ${ }^{146}$ With tangible results similar to the post-combat looting, the lack of anticipation had an unnecessary negative impact on the lives of thousands of Panamanians.

A fifth factor, civil-military cooperation, had mixed results of effectiveness. Before the conflict, inadequate interagency coordination hindered planning. The DOD compartmentalized planning at excessively high classification levels, severely limiting civilian government agencies’

${ }^{143}$ Cole, 42.

${ }^{144}$ Shultz, In the Aftermath of War, 33-7. The DOS program was the International Criminal Investigative Training Assistance Program (ICITAP), a 120-hour program to train Panamanians and bolster the Panamanian National Police (PNP).

${ }^{145}$ Operation "Just Cause": The Human Cost of Military Action in Panama (Boston, MA: Physicians for Human Rights, 1991), 4.

${ }^{146}$ Ibid., 28-30. 
access and preventing much important coordination from taking place. ${ }^{147}$ However, despite the poor interagency planning for stability tasks, civil-military cooperation during execution of the campaign proved to be an effective tool in the conduct of stability operations. In late January 1990 after the military adapted to the post-combat situation, the military proved quite effective in its coordination efforts. For a variety of reasons, chiefly a lack of volunteers, the embassy lacked a staff for nearly six weeks after the invasion. ${ }^{148}$ With the absence of a country team, the MSG assumed the team's duties. In that capacity, the MSG developed good relations with the newly installed GOP. The Army implemented a process to vet and approve all projects through the government. ${ }^{149}$ In this process, local-level government officials recommended projects up to the national-level ministers, who decided which projects to approve and implemented them in conjunction with MSG assistance. ${ }^{150}$ Inclusion of the Panamanian government in the process gave ownership to the projects, as well as created rapport and legitimacy for the newly appointed government.

Long-term United States success in Panama came from the ability of commanders on the ground to adapt to the quickly changing environment. While some observers take this success for granted as merely another example of the effective use of U.S. military power, the operation could have achieved the same success with greater efficiency or worse, failed, if, military and government personnel had accounted for the deficiencies noted above. Five key factors influenced the efficiency and effectiveness of stability tasks and operations: narrow institutional thinking; the development by two separate organizations of two distinct portions of the

\footnotetext{
${ }^{147}$ Shultz, "The Post-Conflict Use of Military Forces: Lessons from Panama, 1989-91," 150; Fishel, The Fog of Peace, 21.

${ }^{148}$ Shultz, In the Aftermath of War, 40.

${ }^{149}$ Ibid., 55.

${ }^{150}$ Ibid., 56.
} 
operational plan; limited military objectives that did not include elements of stability; and a lack of simultaneous execution of stability and offense; and civil-military coordination from the initial planning meeting until the transition of authority back to civil authorities. These factors nearly overturned the overwhelming success of the initial invasion. However, in the end a reasonably successful stability effort contributed to the ultimate success of American intervention in Panama.

\section{Conclusion}

\section{Summary}

This section focuses on a comparative analysis of the two case studies, facilitated by the evaluative factors that reveal the varying degrees of effectiveness in stability operations. The findings from this comparative study then inform an examination of current doctrine, strategic guidance, and policy strengths and weaknesses, which reveals challenges for the Army with respect to each factor as it learns and modifies ULO doctrine.

First, institutional thinking both enabled and hindered planning and execution of stability operations. In the Philippines, institutional thinking was not constrained by any certain type of conflict or threat, and doctrine supported preparation for a multitude of operations. During Operation Just Cause, the large-scale conventional threat posed by the Soviet Union in the preceding decades dominated institutional thought and doctrine, leading to poor understanding of limited warfare throughout much of the Army. ${ }^{151}$ Recognition of potential warfare methods and associated types of threat is a strength of ULO. Current Army doctrine requires leaders to remain competent and trained to operate across the range of military operations, and it underscores the likelihood of facing hybrid threats in the future. ${ }^{152}$ By focusing on the ability to operate across the

\footnotetext{
${ }^{151}$ Ramsey, A Masterpiece of Counterguerrilla Warfare, 16; Witt, 2; War Department, Troops in Campaign, 2-3; Matloff, 280-300; Herring, 816, 824, 872, 877, 888, 891; Headquarters, Department of the Army, FM 100-5 (1986), i.

${ }^{152}$ Headquarters, Department of the Army, Army Doctrine Reference Publication 3-0: Operations
} 
entire range of military operations and conflict continuum against an enemy that employs conventional and unconventional forces and tactics, the modern U.S. Army's institutional approach is not restricted to one grammar of war or form of warfare. In addition to doctrine, national policy as described in the NSS prescribes preparation against a myriad of threats, including conventional, asymmetric, cyber, and terrorist attacks, again not confining thought to one type of conflict. ${ }^{153}$ President Barack Obama reiterated that broad focus in his 2012 paper on sustaining global leadership. In it, he wrote that the Joint Force must be prepared to disrupt and defeat violent extremists, and deter and defeat aggression by any capable state. ${ }^{154}$

To maintain institutional thinking that accepts uncertainty and does not return to an overemphasis on one specific type of conflict, the Army must not forget the lessons of the past ten years as it did after Vietnam. It must continue to expand institutional thought regarding the potential for warfare within other domains, such as space and cyber. This is particularly noteworthy because in the global leadership strategy, the President noted that while U.S. forces must be able to conduct stability and counterinsurgency, they will "no longer be sized to conduct large-scale, prolonged stability operations." 155

Second, the Philippines and Panama case studies illustrated two methods of preparing campaign plans. Commanders during the Philippine War developed a single campaign plan from which subordinate commanders developed district-level plans for pacification. By contrast, when planning for intervention in Panama, USSOUTHCOM developed one plan for combat operations and another for post-combat stability. Further, two different organizations conducted the

(Washington, DC: Headquarters, Department of the Army, 2011), 1-3, 1-8.

${ }^{153}$ White House, National Security Strategy. (Washington, DC: The White House, 2010), 5, 18.

${ }^{154}$ Department of Defense, Sustaining U.S. Global Leadership: Priorities for $21^{\text {st }}$ Century Defense. (Washington, DC: Department of Defense, 2012), 4.

${ }^{155}$ Ibid., 6. 
unsynchronized plans. ${ }^{156}$ ULO does not directly address this issue. However, doctrine does describe an operations process in which Army planners and units address problems holistically. ADRP 5-0: The Operations Process follows the joint planning construct, which emphasizes plan development through phase V, or transition to civil authorities. From JP 5-0: Joint Operation Planning, "joint planning is end state oriented. Joint plans and orders are developed with strategic and military end states in mind." 157 ADRP 5-0 follows suit and focuses on the desired end state of an operational environment. The description of the end state includes conditions military forces should establish to meet policy objectives, orders, and guidance of higher authorities. ${ }^{158}$ ADRP 5 $O$ also describes planning as a continuous and cyclical process. ${ }^{159}$ Commanders and staffs develop orders in advance of action, but they can refine these plans through fragmentary orders throughout execution. By requiring the development of an initial plan that achieves strategic objectives, doctrine implicitly requires that the initial plan include a concept for transition to civil authorities.

The challenge to holistic campaign development going forward is to enforce planning through the transition to civil authorities. This is a challenge for two reasons. Functions such as governance, economics, and rule of law are outside of the contemporary military's comfort zone, so plans are typically limited to the end of combat. Also, transition can occur in the distant future. To avoid planning for uncertainties, staffs generally prefer to focus on the more immediate problem of combat operations.

${ }^{156}$ Linn, U.S. Army and Counterinsurgency in the Philippine War, 1899-1902, 22; Yates, The U.S. Military Intervention in Panama, 156, 269; Shultz, In the Aftermath of War, 20. 2011), II-1.

${ }^{157}$ Joint Staff, Joint Publication 5-0: Joint Operation Planning (Washington, DC: The Joint Staff,

${ }^{158}$ Headquarters, Department of the Army, Army Doctrine Reference Publication 5-0: The Operations Process (Washington, DC: Headquarters, Department of the Army, 2012), 2-8.

${ }^{159}$ Ibid., 2-1. 
Third, the two case studies illustrate a difference in effectiveness regarding whether or not the initial plan included stability in the mission objectives. In the Philippines, both civilian leadership and military commanders included stability in their end state. ${ }^{160}$ Panama presented a different situation. Civilian leaders included stability in the objectives; however, military commanders omitted stability from their end state. ${ }^{161}$ ULO does not address the inclusion of stability considerations within strategic objectives directly. However, the doctrine does describe comprehensive plan analysis, which would logically include stability and other post-conflict considerations. ADRP 5-0 discusses establishing conditions for the desired end state when conducting conceptual planning. Those conditions enable achievement of strategic policy and objectives. ${ }^{162}$ This statement supports the research of John Fishel. An expert on planning and execution of transition and conflict termination, Fishel wrote:

War termination and transition to a post-conflict peacebuilding development effort are phases of military operations that must be planned in full coordination with war fighting. To be successful, its objectives need to be defined in end state terms with clear supporting objectives that are both military and civil-military in nature. This, in turn, suggests that civil military operations in the post-conflict period-post-conflict activities - may be a necessary condition for victory. Thus, when the political-military and the exclusively military end states are not fully synchronized, strategic victory is that much harder to achieve. ${ }^{163}$

Put simply, civil-military cooperation is important, but the harmonization of objectives achieved through unity of effort may be more so for conflict resolution.

Fourth, one can see efforts to accomplish simultaneous execution of stability tasks with offensive and defensive operations in both case studies, but in one case execution ended up

\footnotetext{
${ }^{160}$ Ramsey, Savage Wars of Peace, 18; Richardson, 220.
}

${ }^{161}$ Watson and Tsouras, eds., 69.

${ }^{162}$ Headquarters, Department of the Army, ADRP 5-0, 2-8.

${ }^{163}$ John T. Fishel, "Beyond Jointness: Civil Military Cooperation in Achieving the Desired EndState," in Beyond Declaring Victory and Coming Home: The Challenges of Peace and Stability Operations, ed. Max G. Manwaring and Anthony James Joes (Westport, CT: Praeger, 2000), 129. 
happening simultaneously while in the other it involved a sequential arrangement of tasks. In the Philippines, commanders conducted stability tasks in conjunction with offense and defense tasks. ${ }^{164}$ In Panama, commanders did not integrate stability tasks effectively with offensive operations. ${ }^{165}$ The simultaneous execution of stability tasks stands out as another strength of ULO. Current Army doctrine repeatedly emphasizes the importance of simultaneous execution of stability tasks along with offense and defense. ${ }^{166}$

The challenge going forward is in the application of doctrine and policy, with training serving as the forcing function to strengthen to linkage between stability, offense, and defense. One can see an illustration of this challenge in a recent dialogue between the Commanding Generals of the National Training Center and Joint Readiness Training Center. The two commanders discuss the future of Combat Training Center (CTC) rotations noting that they have the ability to describe the precise structure of future rotations. Nevertheless, the two commanders believe brigade METLs and missions will continue to take priority over all other requirements. ${ }^{167}$ In short, the training centers cannot maintain emphasis on stability unless brigade commanders also stress it in their essential tasks and mission requirements. Significantly, when the training center commanders discuss generic training themes by warfighting function, they omit stability

\footnotetext{
${ }^{164}$ Linn, The Philippine War, 1899-1902, 6; Ramsey, A Masterpiece of Counterguerrilla Warfare, 119.

${ }^{165}$ Watson and Tsouras, eds., 127; Shultz, In the Aftermath of War, 31.

${ }^{166}$ Headquarters, Department of the Army, ADRP 3-0, 1-1; Headquarters, Department of the Army, ADRP 3-07, 2-1; Headquarters, Department of the Army, Army Doctrine Reference Publication 390: Offense and Defense (Washington, DC: Headquarters, Department of the Army, 2012), 1-2.

${ }^{167}$ Commanding General, National Training Center letter to Commanding General, Joint Readiness Training Center, January 13, 2014.
} 
from the conversation, save one short remark about leveraging unified action partners. ${ }^{168}$ It seems the Army still has work to do integrating stability tasks in its peacetime unit training.

Finally, civil-military cooperation presented challenges in both case studies. In the Philippines, personal tensions and division of duties led to ineffective coordination. ${ }^{169}$ Similarly in Panama, institutional rivalries and lack of trust resulted in ineffective dialogue and coordination. ${ }^{170}$ The exception in Panama was the MSG's coordination efforts with the GOP. By comparison with these operations, ULO doctrine's integration of civil-military coordination is a strength. Like simultaneous execution of stability tasks, ULO mentions civil-military cooperation numerous times. ${ }^{171}$ Further, civil-military coordination is not limited to coordination with USG and Non-Governmental Organizations (NGOs); it also includes host nation civilian agencies. ${ }^{172}$ History demonstrates that commanders should use caution when coordinating with host nation civilian activities. This coordination is a slippery slope because the requirement to coordinate with host nation authorities is a necessity and is categorically a DOS responsibility. However, it is incumbent upon the military to ensure this coordination takes place, with or without help. Panama's Ambassador Deane Hinton noted this dilemma when reflecting on the aftermath of Just Cause. Ambassador Hinton stated the arrangement the military had with the GOP was inappropriate and that it had gone too far. However, he further said such an arrangement was required because of the difficult situation the embassy found itself in while

\footnotetext{
${ }^{168}$ Commanding General, National Training Center letter to Commanding General, Joint Readiness Training Center.

${ }^{169}$ Linn, The Philippine War, 1899-1902, 91, 216.

${ }^{170}$ Shultz, "The Post-Conflict Use of Military Forces: Lessons from Panama, 1989-91," 150; Fishel, The Fog of Peace, 21.

${ }^{171}$ Headquarters, Department of the Army, ADRP 3-0, 1-4; Headquarters, Department of the Army, ADRP 3-07, 1-11; Headquarters, Department of the Army, ADRP 5-0, 3-2.

${ }^{172}$ Headquarters, Department of the Army, ADRP 3-07, 1-3; Headquarters, Department of the Army, ADRP 5-0, 1-10.
} 
attempting to find a staff and conduct operations. ${ }^{173}$ In hindsight, the military overstepped its bounds. Nevertheless, as the Panama intervention illustrates, the immediate security situation or inadequate interagency staffing levels may prevent USG agencies from fulfilling their roles and responsibilities, leaving a void that military forces must fill. ${ }^{174}$

\section{Implications and Recommendations}

The United States will conduct stability operations as part of conflict for years to come. Since the end of the Cold War, the United States has conducted a stabilization operation on average once every one to two years. ${ }^{175}$ There is no reason to believe this trend will cease with dwindling global resources and an exponentially growing population. As such, stability tasks remain a key consideration when seeking to resolve conflict because effective integration of stability operations can assist in achievement of strategic objectives. ${ }^{176}$ Neglecting to learn this lesson from America's military history could prove detrimental to U.S. national interests.

The military develops its theater strategy and campaign plans based on guidance from political leaders. Guidance found in the national security strategy identifies focus areas on which the combatant commands should concentrate their campaign plans to protect America's national interests. The military translates that guidance into doctrine that serves as the basis for military organization, training, and equipment procurement. A misinterpretation, misapplication, or omission of strategic guidance in the development of DOD theater strategy around the world could have catastrophic results. In particular, the focus on major combat against a peer competitor in the Soviet Union, both during and after the Cold War led to de-emphasis of limited war

\footnotetext{
${ }^{173}$ Shultz, In the Aftermath of War, 62-3.

${ }^{174}$ Ibid., 40.

${ }^{175}$ Fields and Odeen, 83.

${ }^{176}$ Yates, Global War On Terrorism Occasional Paper 15, 38.
} 
doctrine. This is particularly true of stability operations since they arguably represents the most important step to conflict resolution, and the U.S. military participated in several limited wars during this time.

From the comparison to ULO and identification as a strength or weakness, this monograph provides a few recommendations to assist in avoiding future pitfalls. First, the military should prepare to assume all aspects of civil administration and build that knowledge into institutional processes. To assume that another entity, either one of the United States or one from the host nation, will immediately assume civil administration responsibilities is a mistake. This error may cause an increase in the level of violence as seen in Panama, rather than provide a stabilizing presence.

As justification for the military's responsibility to prepare for such a task, one simply has to observe the evolution of the Bureau of Conflict and Stabilization Operations (CSO). This organization, which has the responsibility to respond rapidly to a crisis, has adopted a new mission left over by its predecessor, remains understaffed, and lacks the money required to plan, train for, or conduct operations. President Obama created CSO in 2012 as the successor to Office of the Coordinator for Reconstruction and Stabilization (S/CRS), a governmental agency established in 2004. ${ }^{177}$ The Obama administration did not see a direct leadership role in conflict response or broad interagency state building mission as part of CSO's mission. ${ }^{178}$ Further, the Obama administration permanently reduced the Civilian Response Corps (CRC) from a standing size of 250 active and 2,000 reserve personnel to fifty active and 500 reserve personnel. In addition, CSO closed its warehouse in Springfield, Virginia, and disposed of CRC vehicles,

\footnotetext{
${ }^{177}$ United States Department of State, "What We Do," http://www.state.gov/j/cso/what/ index.htm (accessed December 29, 2013).

${ }^{178}$ Nina A. Serafino, In Brief: State Department Bureau of Conflict and Stabilization Operations (Washington, DC: Congressional Research Service, October 10, 2012), 4.
} 
communications equipment, and other gear that was to provide autonomy of action for deployed CRC members. ${ }^{179}$ Lastly, CSO requested \$56.5 million for Fiscal Year 2012, yet Congress approved only $\$ 30.3$ million. ${ }^{180}$

In order to assume such responsibilities, the Army must build a knowledge base and capacity. To fulfill expectations that the military is responsible for such actions until other government agencies arrive to take over, the Army should include portions of the 1962 version of FM 41-10: Civil Affairs Operations in ULO doctrine. FM 41-10 described how the military established and either led or participated in commissions or councils concerned with governmental affairs, development of plans for maintenance, preservation, or restoration of the local economy, economic stabilization measures, determination of means of production and distribution, and price control. ${ }^{181}$

By directing the conduct of such tasks through doctrine, the military creates an expectation and sense of responsibility that U.S. forces are to conduct those types of activities. To address training aimed to accomplish those doctrinal responsibilities, the military could reestablish a school similar to the School of Military Government. This school, created in 1942 and outsourced to the University of Virginia for instruction, was responsible for teaching and developing senior leaders on specifics of managing a government and creating economic growth. ${ }^{182}$ The requirement stemmed from the 1940 FM 27-5: Military Government. FM 27-5 described how the military should conduct governmental functions and public works while

\footnotetext{
${ }^{179}$ Serafino, In Brief: State Department Bureau of Conflict and Stabilization Operations, 7.

${ }^{180}$ Ibid., 9.

${ }^{181}$ Headquarters, Department of the Army, Field Manual 41-10: Civil Affairs Operations
} (Washington, DC: Headquarters, Department of the Army, 1962), 20, 27, 29.

${ }^{182}$ Earl F. Ziemke, The U.S. Army in the Occupation of Germany 1944-1946 (Washington, DC: Center of Military History, 1975), 12; Edmund Berkley, Jr., senior University of Virginia archivist, correspondence with Ms. Anne Collins McNeal, September 9, 1998. 
supervising an occupied territory's fiscal matters, public health and safety, education, and legal system. ${ }^{183}$ President Franklin D. Roosevelt acknowledged that governing civilian territory is a civilian function, but the War Department, with Roosevelt's concurrence, understood that the military was obligated to "set up and maintain military government" until such a time civilian authority could supplant military control. ${ }^{184}$

As another means to improve the Army's ability to conduct effective stability operations, commanders at all levels should develop one comprehensive plan that includes combat and postcombat tasks and operations. Doing so addresses development of a holistic plan and inclusion of stability elements in the end state. Combat operations in conflicts such as Just Cause, Desert Storm, and the initial invasion of Iraqi Freedom occurred so quickly that forces achieved "catastrophic success," leaving them flat-footed when the time came to transition to post-conflict activities. These operations demonstrate the need to plan beyond the major combat phases to the stabilization and transition phases. However, because the possibility of a prolonged operation exists, the planning should remain conceptual until such a time that detailed plans are required for implementation. A conceptual plan addresses the entire problem yet does not provide the final solution for action, thus avoiding three of the four potential pitfalls in ADRP 5-0. ${ }^{185}$ To develop a comprehensive plan, the commander begins with a visualization of the desired operational environment, which includes functional civilian systems and infrastructure upon transition to host

\footnotetext{
${ }^{183}$ War Department, FM 27-5: Military Government, (Washington, DC: Government Printing Office, 1940), 7-9.

${ }^{184}$ Ziemke, 11.

${ }^{185}$ Headquarters, Department of the Army, ADRP5-0, 2-24. The three pitfalls addressed are planning in too much detail, using planning as a scripting process, and producing plans that emphasize detailed procedures and structured thinking.
} 
nation civil authorities. ${ }^{186}$ This provides a better set of conditions to work toward rather than using the end of hostilities as the desired end state and adapting after that. ${ }^{187}$

One point of consideration when developing end states is that they should consider historical context. For example, during Operation Just Cause one of the strategic objectives was democratization of Panama. One wonders whether that objective was even achievable because throughout the history of Panama, it had an oligarchic form of government led by a handful of upper-class families. This system remained in place until 1968, when General Omar Torrijos seized power through a military coup and a military dictator ruled Panama until United States intervention in 1989. ${ }^{188}$ Given Panama's historical, societal, and cultural norms, it might have been unrealistic to expect to install a democracy there as one of the objectives of Operation Just Cause. To facilitate better development of end states that complement strategic objectives, one relative weakness of ULO is its lack of explanation of how to develop attainable objectives. Given the fact that the military develops its objectives to support national objectives, ULO should incorporate development of military objectives in its planning doctrine. Additionally, ADRP 5-0 should include a section on objective development within the Army design methodology section.

Third, the military should continue its integrated coordination effort with civilian entities. As seen in the post-combat situation in Panama, a close relationship with civil authorities - both those of the United States and the host nation - fosters an environment that produces unity of effort and more efficiently works toward long-term stabilization. Provincial Reconstruction Teams are a great start to that civilian-military dialogue, but the potential exists to do even more

${ }^{186}$ Headquarters, Department of the Army, ADRP 5-0, 2-8.

${ }^{187}$ John T. Fishel, "Beyond Jointness: Civil Military Cooperation in Achieving the Desired EndState," 109. Fishel stated that national policy objectives are rarely "translated to military end states and attainable supporting objectives."

${ }^{188}$ Shultz, “The Post-Conflict Use of Military Forces: Lessons from Panama, 1989-91,” 147. 
in this aspect of operational planning. ${ }^{189}$ The important factor, as demonstrated by the two case studies, is bearing in mind that the military is subordinate to civilian authorities. Should personalities or egos become the defining part of a civil-military relationship, this could lead to mission failure. One potential solution already proposed through professional dialogue is subordinating the military to a civilian chain of command at a lower level than the National Security Council. ${ }^{190}$

A fourth recommendation is to continue executing stability tasks simultaneously with offensive and defensive tasks. By conducting stability tasks concurrently, the military develops relationships early in the conflict, creates an environment of legitimacy by conducting activities other than combat and the destruction that accompanies it, and it begins post-combat activities at the earliest possible moment. All of these benefits further the effort to achieve peace and stability rather than simply ending combat operations. ${ }^{191}$ Inclusion of stability as an equal component of the various training activities when allocating resources might resolve solve some of these issues. The Army accomplishes this by addressing stability in unit METLs and utilizing the hybrid threat model in all training scenarios. The Army training centers have incorporated the hybrid threat

${ }^{189}$ Hew Strachan, "Making Strategy: Civil-Military Relations After Iraq," Survival 48, no. 3 (Autumn 2006): 77.

${ }^{190}$ Jeffrey Buchanan, Maxie Y. Davis, and Lee T. Wright, "Death of the Combatant Command? Toward a Joint Interagency Approach,” Joint Force Quarterly 52, no. 19 (January 2009): 94. The authors propose the creation of organizations called Joint Interagency Commands (JIACOMs) that report to the National Security Council. These organizations would be "standing, civilian-led interagency organizations, with regional responsibility for all aspects of U.S. foreign policy, reporting directly to the President through the NSC. These entities' formal structure would include representatives from all major Federal Government agencies, including DOD, while dissolving the existing geographic combatant commands." The organizations would have a credentialed civilian with potentially a General Officer as a deputy. Further, they "would be an operational-level organization responsible for planning, integrating, and executing all U.S. regional foreign policy. It would contain or have direct access to and tasking authority over all U.S. agencies likely to be involved in planning and implementing these policies, up to and including the use of military force."

${ }^{191}$ Headquarters, Department of the Army, ADRP 3-07, 1-2; Gentile, "The Civilian Side," Afghan Quest; SOLLIM Sampler, 14, 21. 
into decisive action training environment rotations, so this solution has widespread support. ${ }^{192}$ However, incorporating stability as a mission essential task (MET) still poses a problem.

In 2010, Forces Command directed like-type units at the Brigade level and above to have standardized mission essential tasks (METs). ${ }^{193}$ The three Corps adopted the standardized METs, slightly modifying them to account for their specific missions. After incorporating the adjustments and analyzing the final outcomes, stability accounted for no more than one MET on any of the units' lists; and depending upon the Corps, that single task focused on either coordinating interagency support or public safety and security. ${ }^{194}$ In order to place emphasis on Army unit execution of stability tasks, core METs should include other stability-related areas, such as encompassing task groups for political and economic functions. This inclusion provides a training focus throughout the Army Force Generation cycle. Including such tasks as mission essential, subordinate divisions, brigades, and battalions will nest their METLs with the Corps' through a METL crosswalk as required in Army training management. ${ }^{195}$

If the Army is to avoid relearning lessons from past conflicts in the future, it must take the opportunity now, as it enters a post-war period, to review its doctrine and training to ensure it devotes adequate attention to stability tasks. Without change, the United States Army risks repeating the mistakes highlighted in the case studies above, and others experienced in similar operations. A focus on inclusion of stability in planning, doctrine, and training may redefine the

\footnotetext{
${ }^{192} \mathrm{C}$. Todd Lopez, "Army Training for Date with Hybrid Threats," Official Homepage of the United States Army, November 14, 2012, http://www.army.mil/article/91010/ (accessed January 26, 2014); United States Army, "Decisive Action Training Environment," STAND-TO!, March 08, 2012, http://www.army.mil/standto/ archive/issue.php?issue=2012-03-08 (accessed January 26, 2014).

${ }^{193}$ Training Management Directorate, "Department of the Army Standardized METL Information Brief" (Fort Leavenworth, KS: Combined Arms Center-Training, 2013).

${ }^{194}$ Mission Essential Task List, I Corps, 2013; Mission Essential Task List, III Corps, 2013; Mission Essential Task List, XVIII Airborne Corps, 2013.

${ }^{195}$ Headquarters, Department of the Army, Army Doctrine Reference Publication 7-0: Training Units and Developing Leaders (Washington, DC: Headquarters, Department of the Army, 2012), 3-2.
} 
hierarchy of decisive action tasks, aligning them more closely with future realities, and shift thinking about what constitutes a tactical action. The Army must expand how it approaches tactical engagements and operational art, providing commanders a fresh outlook on the criticality of successful accomplishment of stability tasks in achieving mission success. 


\section{BIBLIOGRAPHY}

Birtle, Andrew J. U.S. Army Counterinsurgency and Contingency Operations Doctrine 18601941. Washington, DC: Government Printing Office, 1998.

Briggs, Clarence E. III. Operation Just Cause a Soldier's Eyewitness Account: Panama, December 1989. Harrisburg, PA: Stackpole Books, 1990.

Buchanan, Jeffrey, Maxie Y. Davis, and Lee T. Wright. "Death of the Combatant Command? Toward a Joint Interagency Approach.” Joint Force Quarterly 52, no. 19 (January 2009): 92-96.

Bush, George W. "Supporting Emerging Democracies." International Republican Institute Dinner, Renaissance Hotel, Washington, DC, May 17, 2005. http://2001-2009.state.gov/ s/crs/rls/rm/46818.htm (accessed December 29, 2013).

Clausewitz, Carl. On War, Indexed Edition. Reprint ed. Translated and edited by Michael Howard and Peter Paret. Princeton, NJ: Princeton University Press, 1989.

Cole, Ronald H. Operation JUST CAUSE: the Planning and Execution of Joint Operations in Panama. Washington, DC: Joint History Office, 1995.

Department of Defense. Sustaining U.S. Global Leadership: Priorities for $21^{\text {st }}$ Century Defense. Washington, DC: Department of Defense, January 2012.

Department of Defense Instruction 3000.05: Stability Operations. Washington, DC: Department of Defense, September 16, 2009.

Elsea, Jennifer K., and Matthew C. Weed. Declarations of War and Authorizations for the Use of Military Force: Historical Background and Legal Implications. Washington, DC: Congressional Research Service, January 11, 2013.

Echevarria, Antulio J. II. "American Operational Art, 1917-2008." In The Evolution of Operational Art: from Napoleon to the Present, edited by John Andreas Olsen and Martin van Creveld, 137-165. Oxford: Oxford University Press, USA, 2011.

Fields, Craig I., and Philip A. Odeen. Transition to and from Hostilities Volume II. Washington, DC: Defense Science Board, January 2005.

Fishel, John T. "Beyond Jointness: Civil Military Cooperation in Achieving the Desired EndState." In Beyond Declaring Victory and Coming Home: The Challenges of Peace and Stability Operations, edited by Max G. Manwaring and Anthony James Joes, 107-34. Westport, CT: Praeger, 2000.

The Fog of Peace: Planning and Executing the Restoration of Panama. Carlisle Barracks, PA: Strategic Studies Institute, U.S. Army War College, 1992.

Gates, John M. The U.S. Army and Irregular Warfare. Wooster: College of Wooster, 2002. http://www3.wooster.edu/history/jgates/pdfs/fullbook.pdf (accessed December 12, 2013). 
Gentile, Gian. “The Civilian Side.” Afghan Quest (blog), January 05, 2011.

http://afghanquest.com/?tag=col-gian-gentile (accessed November 26, 2013).

Headquarters, Department of the Army. Army Doctrine Publication 3-0: Operations.

Washington, DC: Headquarters, Department of the Army, 2011.

. Army Doctrine Reference Publication 1-02: Operational Terms and Military Symbols. Washington, DC: Headquarters, Department of the Army, 2012.

. Army Doctrine Reference Publication 3-0: Operations. Washington, DC:

Headquarters, Department of the Army, 2012.

. Army Doctrine Reference Publication 3-07: Stability. Washington, DC: Headquarters, Department of the Army, 2012.

. Army Doctrine Reference Publication 3-90: Offense and Defense. Washington, DC:

Headquarters, Department of the Army, 2012.

. Army Doctrine Reference Publication 5-0: The Operations Process. Washington, DC:

Headquarters, Department of the Army, 2012.

. Army Doctrine Reference Publication 7-0: Training Units and Developing Leaders.

Washington, DC: Headquarters, Department of the Army, 2012.

Field Manual 41-10: Civil Affairs Operations. Washington, DC: Headquarters, Department of the Army, 1962.

. Field Manual 100-5: Operations. Washington, DC: Headquarters, Department of the Army, 1986.

. Field Manual 100-5: Operations. Washington, DC: Headquarters, Department of the Army, 1993.

. Field Manual 100-20: Low Intensity Conflict. Washington, DC: Headquarters, Department of the Army, 1986.

Herring, George C. From Colony to Superpower: U.S. Foreign Relations Since 1776. New York: Oxford University Press, 2008.

Hunt, Elvid. History of Fort Leavenworth 1827-1927. Fort Leavenworth, KS: Command and General Staff School Press, 1937.

Joint Staff. Joint Publication 3-07: Stability. Washington, DC: Department of Defense, September 2011.

. Joint Publication 5-0: Joint Operation Planning. Washington, DC: Department of Defense, August 2011.

Kagan, Robert. Dangerous Nation. New York: Alfred A. Knopf, 2006. 
King, Benjamin. Victory Starts Here: A 35-Year History of U.S. Army Training and Doctrine Command. Fort Leavenworth, KS: Combat Studies Institute Press, 2008.

Linn, Brian McAllister. The Philippine War, 1899-1902. Lawrence: University Press of Kansas, 2000.

U.S. Army and Counterinsurgency in the Philippine War, 1899-1902. Chapel Hill: The University of North Carolina Press, 2000.

. "War Termination." Proceedings of the War Termination Conference at USMA, West Point, NY, June 21, 2010.

Lochlear, James R. III. Peacetime Engagement Conference Report. Washington, DC: Assistant Secretary of Defense for Special Operations and Low-Intensity Conflict, July 12, 1991.

Lopez, C. Todd. “Army Training for DATE with Hybrid Threats." Official Homepage of the United States Army. November 14, 2012, http://www.army.mil/article/91010/ (assessed January 26, 2014).

Matloff, Maurice, ed. American Military History. 1969. Army Historical Series. Reprint, Washington, DC: Office of Military History, 1988.

McCormick, Michael. "The New FM 100-5: A Return to Operational Art." Military Review 77, no. 5 (September-October 1997): 3-14.

Miller, Stuart Creighton. Benevolent Assimilation: The American Conquest of the Philippines, 1899-1903. New Haven: Yale University Press, 1982.

Mokhiber, Jim, and Rick Young. "The Uses of Military Force.” http://www.pbs.org/wgbh/ pages/frontline/shows/military/force/ (accessed December 29, 2013).

Operation "Just Cause": The Human Cost of Military Action in Panama. Boston, MA: Physicians for Human Rights, 1991.

Otis, Elwell S. 1883 Infantry and Cavalry School Annual Report. Fort Leavenworth, KS: Combined Arms Research Library, 1883, http://usacac.army.mil/cac2/cgsc/ carl/download/reports/rep1883.pdf (accessed December 16, 2013).

Phillips, R. Cody. Operation Just Cause: the Incursion Into Panama. Washington, DC: Center of Military History, 1991.

Ramsey, Robert D. III. A Masterpiece of Counterguerrilla Warfare: BG J. Franklin Bell in the Philippines, 1901-1902. Fort Leavenworth, KS: Combat Studies Institute Press, 2007. . Savage Wars of Peace: Case Studies of Pacification in the Philippines, 1900-1902. Fort Leavenworth, KS: Combat Studies Institute Press, 2007.

Richardson, James D. Messages and Papers of the Presidents 1789-1897 - Volume X. Washington, DC: Government Printing Office, 1899. 
Romjue, John L., Susan Canedy, and Anne W. Chapman. Prepare the Army for War: A Historical Overview of the Army Training and Doctrine Command, 1973-1993. TRADOC Historical Studies. Fort Monroe, VA: Office of the Command Historian, United States Army Training and Doctrine Command, 1993.

Serafino, Nina A. In Brief: State Department Bureau of Conflict and Stabilization Operations. Washington, DC: Congressional Research Service, October 10, 2012.

Peacekeeping and Related Stability Operations: Issues of U.S. Military Involvement. Washington, DC: Congressional Research Service, October 4, 2004.

Serafino, Nina M., and Martin A. Weiss. Peacekeeping and Conflict Transitions: Background and Congressional Action on Civilian Capabilities. Washington, DC: Congressional Research Service, April 13, 2005.

Shultz, Richard H. Jr. In the Aftermath of War U.S. Support for Reconstruction and NationBuilding in Panama Following JUST CAUSE. Maxwell AFB, AL: Air University Press, 1993.

. "The Post-Conflict Use of Military Forces: Lessons from Panama, 1989-91." The Journal of Strategic Studies 16, no. 2 (June 1993): 145-72.

Smith, Rupert. The Utility of Force: the Art of War in the Modern World. 1st ed. New York: Vintage, 2008.

SOLLIM Sampler: Targeting Peace and Stability Operations Lessons and Best Practices: Lessons on Stability Operations from U.S. Army War College Students. Carlisle, PA: U.S. Army Peacekeeping and Stability Operations Institute, August 2013.

Strachan, Hew. "Making Strategy: Civil-Military Relations After Iraq.” Survival 48, no. 3 (Autumn 2006): 59-82.

United States Army. "Decisive Action Training Environment." STAND-TO! March 08, 2012. http://www.army.mil/ standto/archive/issue.php?issue=2012-03-08 (accessed January 26, 2014).

United States Army Training and Doctrine Command. Transforming the Army: TRADOC's First Thirty Years - 1973-2003. TRADOC Historical Studies. Fort Monroe, VA: Military History Office United States Army Training and Doctrine Command, 2003.

United States Department of State. "Careers at Department of State." The Office of Website Management, Bureau of Public Affairs, http://www.state.gov/careers/ (accessed December 29, 2013). . "Office of the Coordinator for Reconstruction and Stabilization." January 20, 2009. http://2001-2009.state.gov/s/crs/ (accessed December 29, 2013).

. "What We Do." http://www.state.gov/j/cso/what/index.htm (accessed December 29, 2013). 
United States Institute of Peace. Guiding Principles for Stabilization and Reconstruction. Washington, DC: United States Institute of Peace Press, 2009.

War Department. Troops in Campaign: Regulations for the Army of the United States. Washington, DC: Government Printing Office, 1892.

Field Manual 27-5: Military Government. Washington, DC: Government Printing Office, 1940.

Watson, Bruce W., and Peter G. Tsouras, eds. Operation JUST CAUSE: the U.S. Intervention in Panama. Boulder: Westview Press, 1991.

Weinberger, Caspar W. "The Uses of Military Power." Speech, National Press Club, Washington, DC, November 28, 1984. http://www.pbs.org/wgbh/pages/frontline/shows/military/ force/weinberger.html (accessed December 29, 2013).

White House. National Security Decision Directive 238. Washington, DC, 1986. . National Security Strategy of the United States. Washington, DC, 1987. . National Security Strategy of the United States. Washington, DC, 1988. . National Security Strategy of the United States. Washington, DC, 2010.

Witt, John Fabian. Lincoln's Code: the Laws of War in American History. New York: Free Press, 2013.

Yates, Lawrence A. Global War on Terrorism Occasional Paper 15. The U.S. Military's Experience in Stability Operations, 1789-2005. Fort Leavenworth, KS: Combat Studies Institute Press, 2006.

. The U.S. Military Intervention in Panama: Origins, Planning, and Crisis Management, June 1987-December 1989. Washington, DC: Center of Military History, 2008.

Ziemke, Earl F. The U.S. Army in the Occupation of Germany 1944-1946. Washington, DC: Center of Military History, 1975. 